دراسات في آثار الوطن العربيَ 1

\title{
رأس من العصر البطلمى
}

د. عزيزة حسن السيد سليمان محجوب•

رأس من الجرانيت الوردى أبعادها ( الطول ○. اب سم ، العرض 9Y سم ، القطر

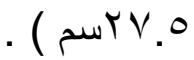

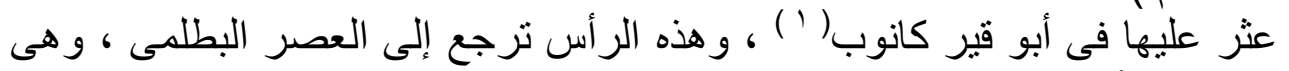

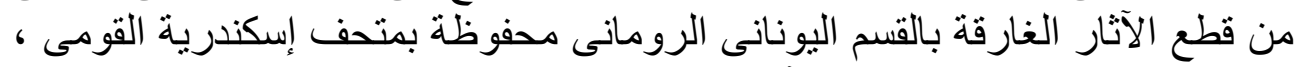

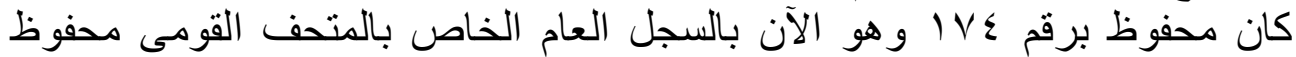

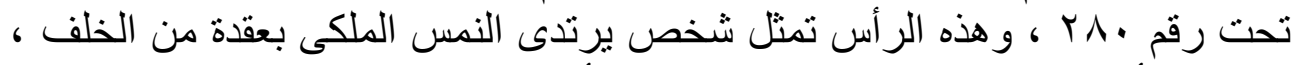
الجانب الأيسر من النمس و الرقبة مكسورة و والأنف بحالة سيئة .

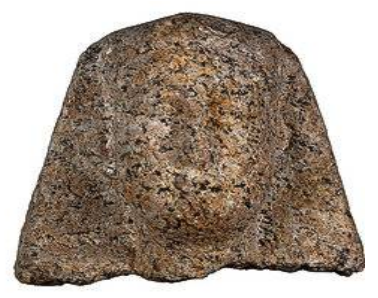

الوصف والتحليل

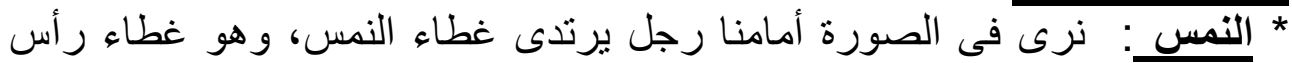

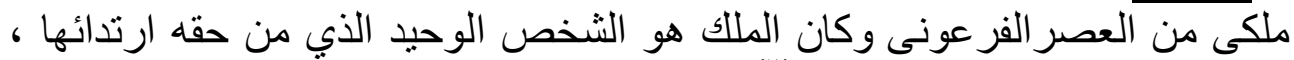

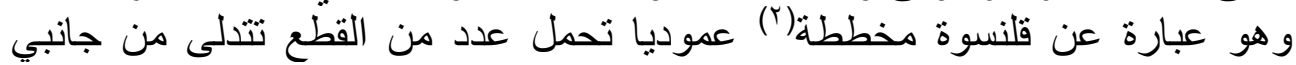

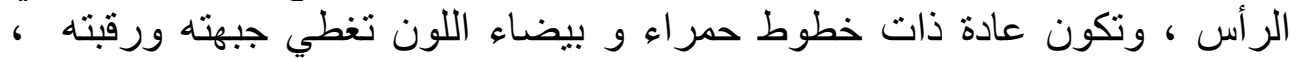

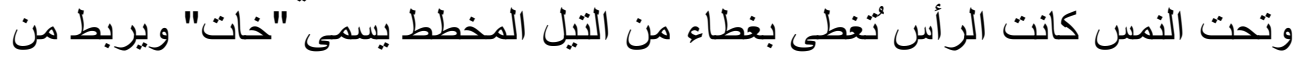

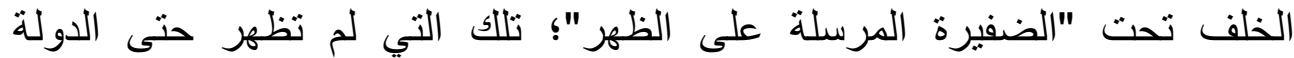
الوسطى ، وير اعى بعد وضع النمس فوقه على الر أس أن تجمع الأطر اف الخلفية

• أستاذ مساعد الآثار اليونانية والرومانية كلية الآداب - جامعة المنصورة

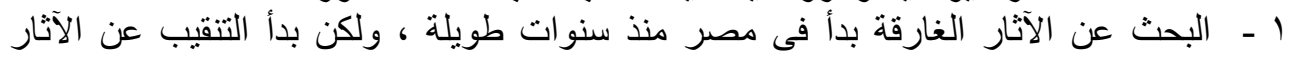

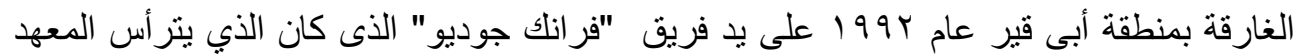

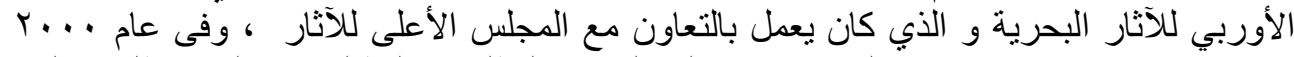

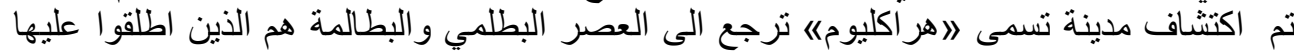

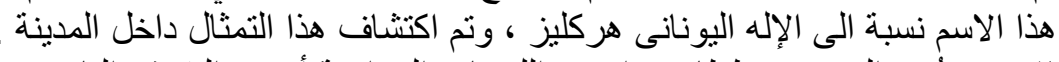

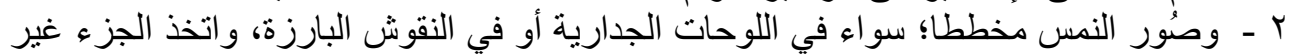

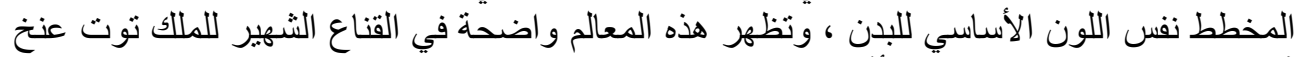

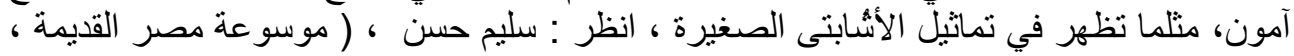

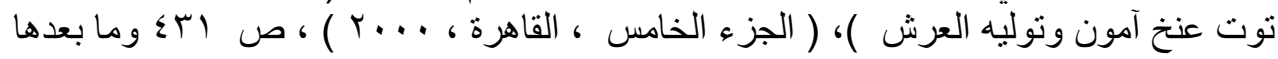
$|r$. 


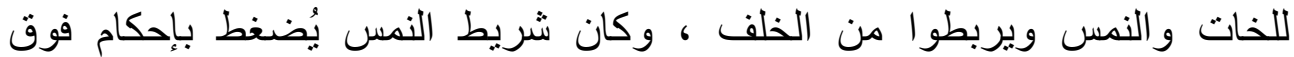

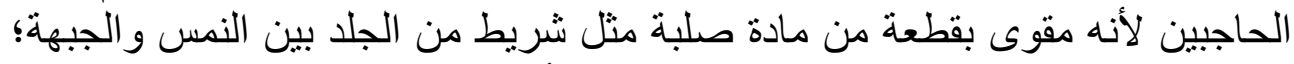

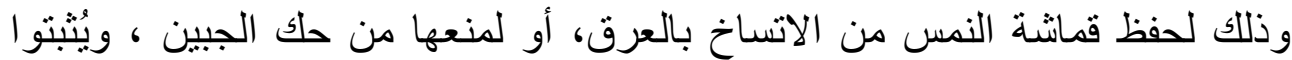

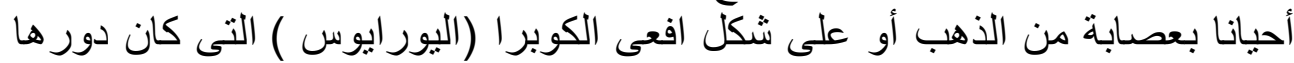

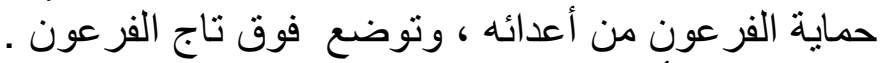

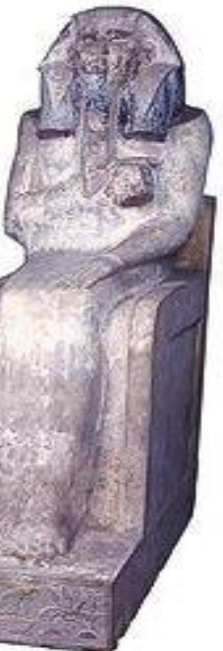

تمثال للملك زوسر بغطاء

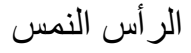

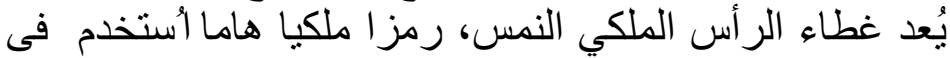

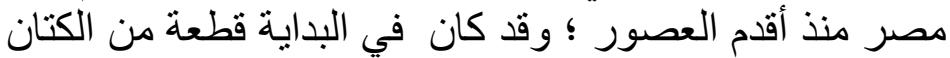

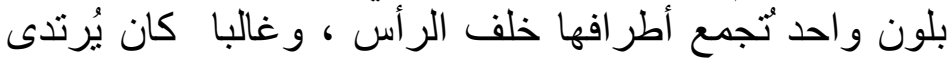

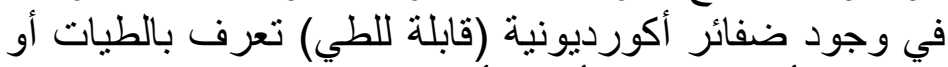

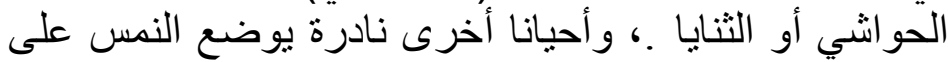

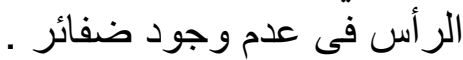

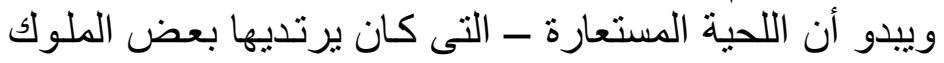

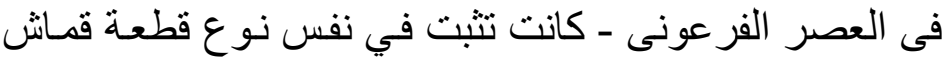

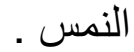
وخير الأمثلة على ارتداء الملوك للنمس منذ أقدم العثور هـى

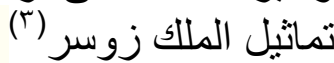

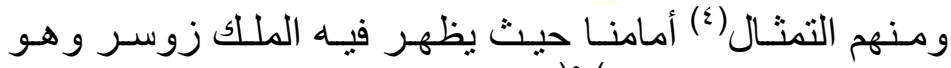

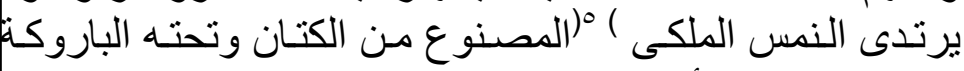
مقسمه إلي ثناث أجز اء جزئان امامي وجزء المن خلفي .

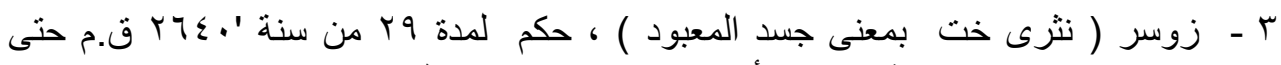

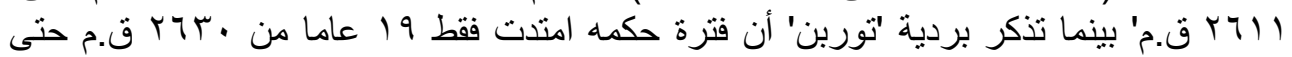

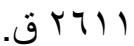
ـ - ـ تمثال من الحجر الجيرى الملون عُثر عليه في حجرة ضيقة تعرف باسم السرداب، وتقع شمال

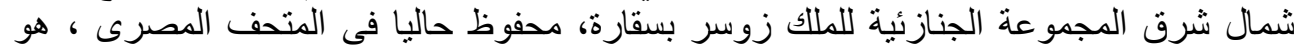

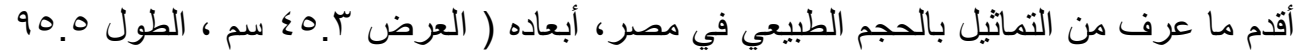

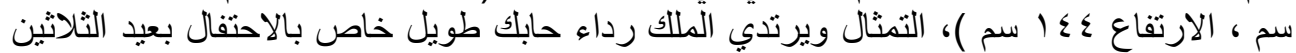

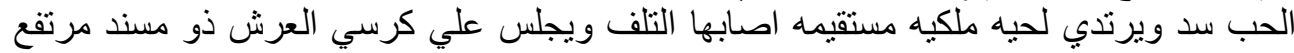

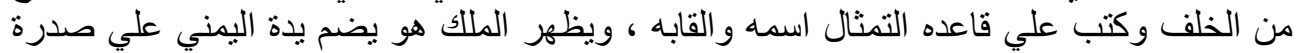
ويده البسري يضعها علي ركبته اليست اليسري.

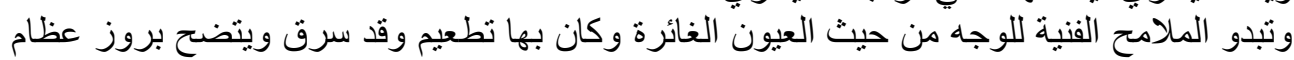

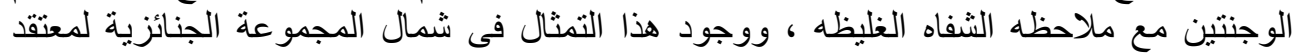

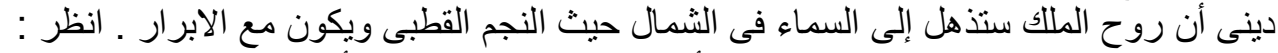

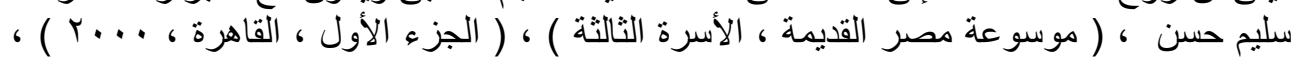
rVA ص صلriv

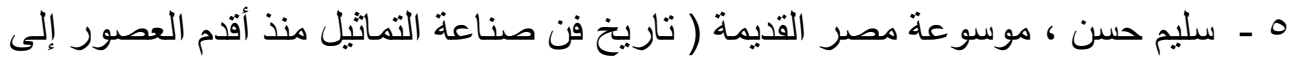

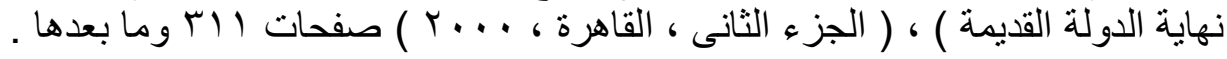


ظهور الملك صـاحب الـر أس موضـوع البحث بتـاج النمس شـئ أساسـى فـى مصـر ارض الفر اعنة فقد كانت التيجان فى مصر القديمة تلعب دور التها هاما و كبير فئ في الحياة

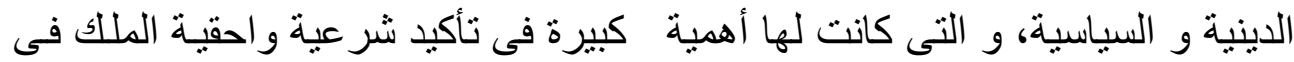

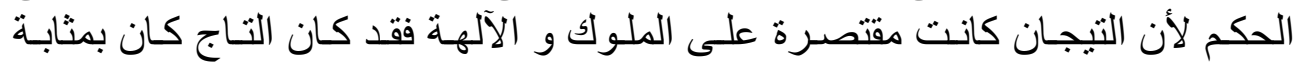

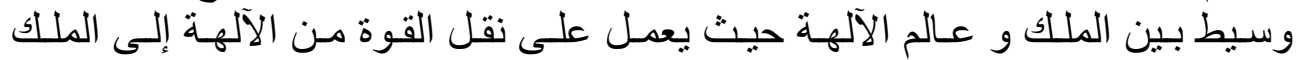

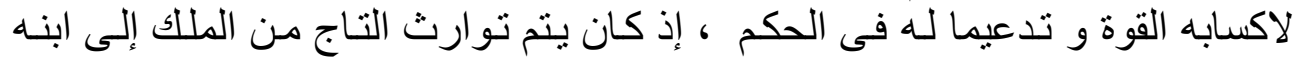

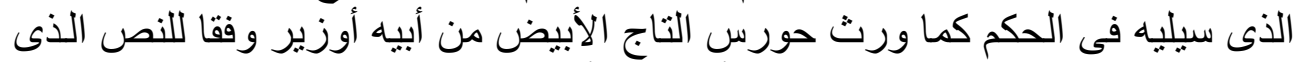

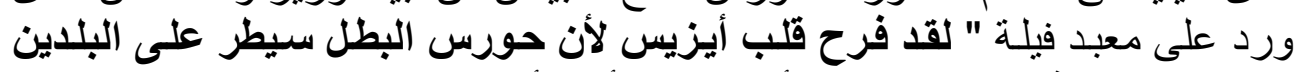

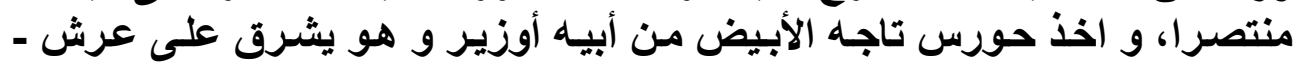

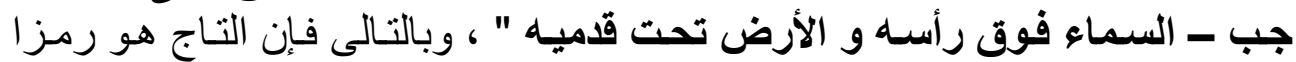

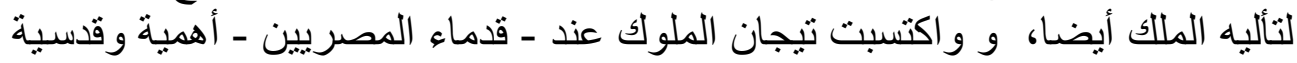

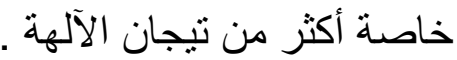

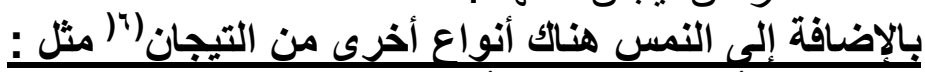

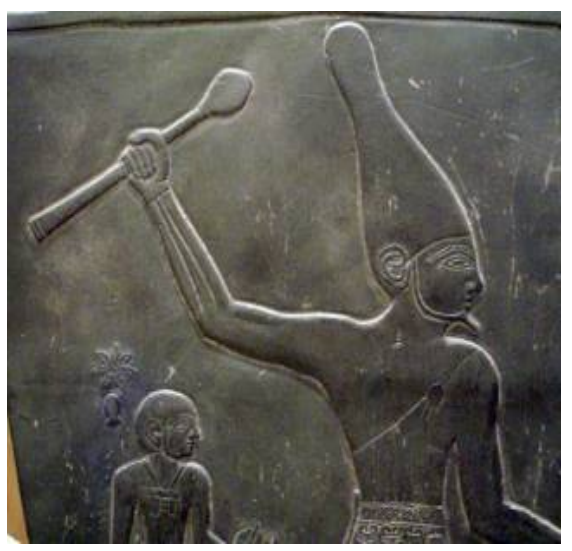

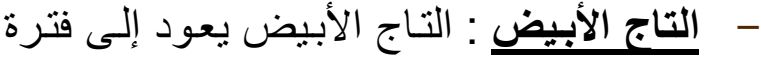

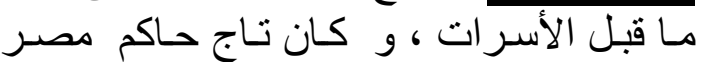

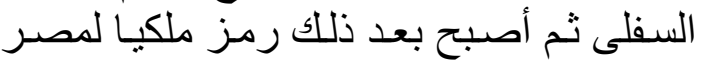

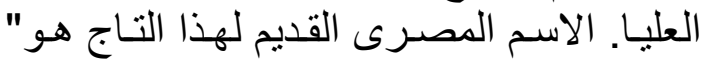

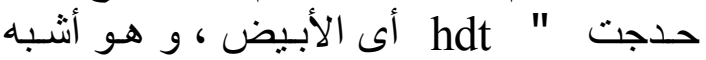

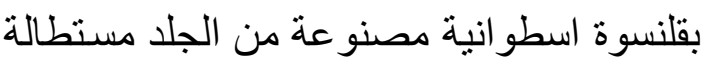

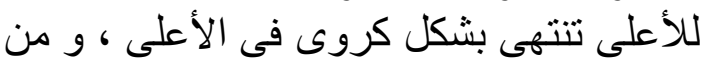

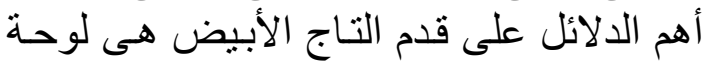

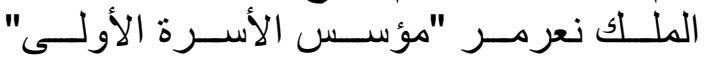

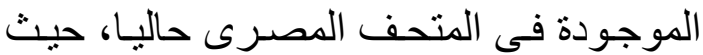

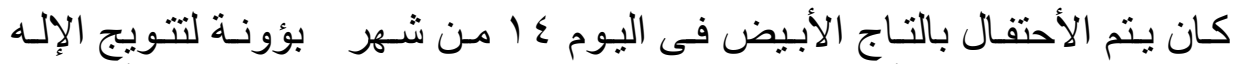

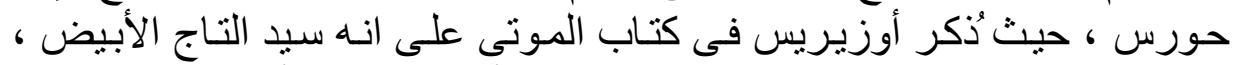

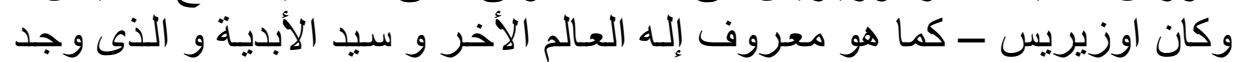

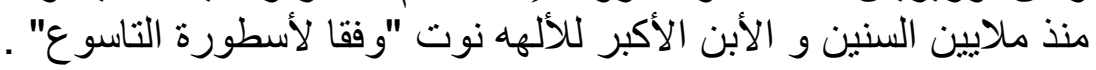

7 - جفرى بارندر، المعتقدات الدينية لدى الشعوب، ثرجمة إمام عبد الفتاح إمام، عالم

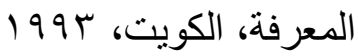


دراسات في آثار الوطن العربيَ 1

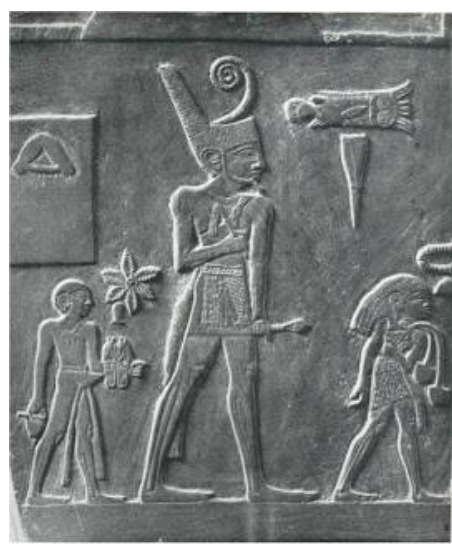

-التاج الأحمر : تز امن وجوده مع التاج الأبيض ،

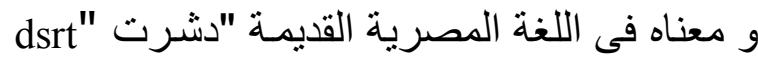

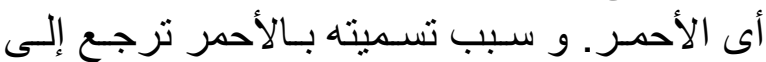

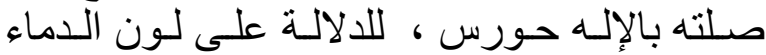

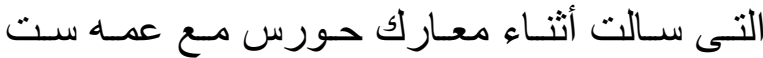

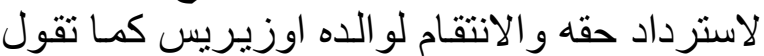

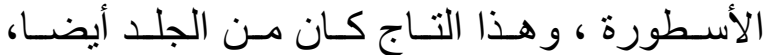

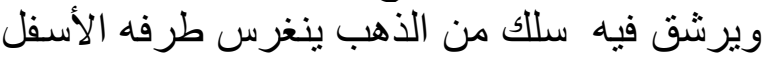

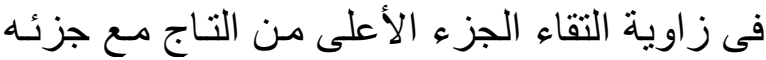

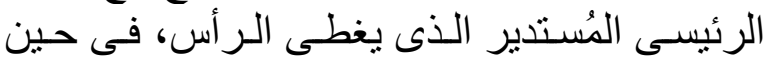

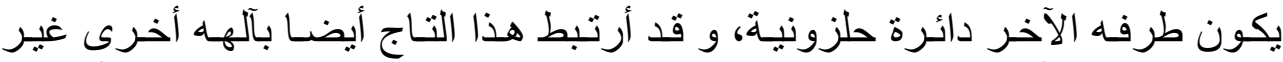

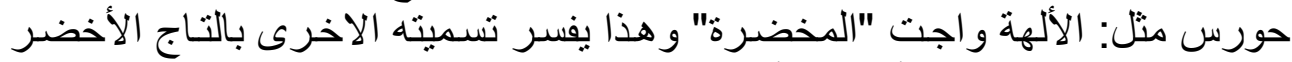

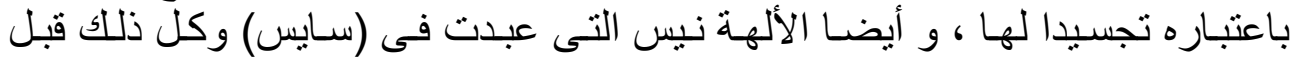

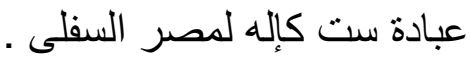

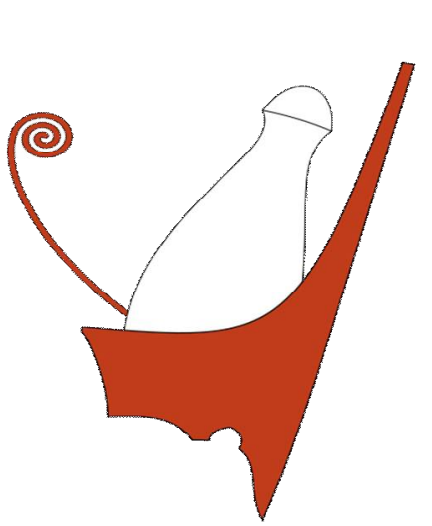
-

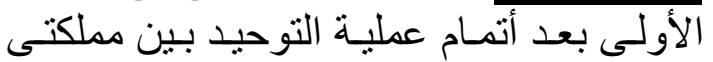

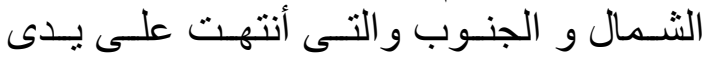

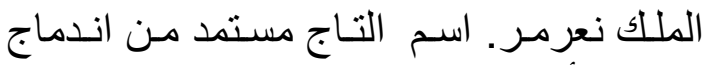

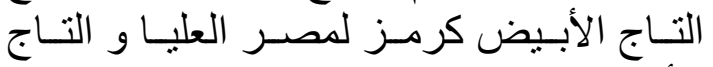

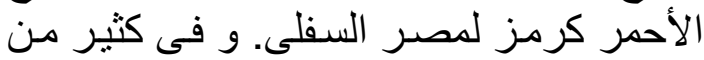

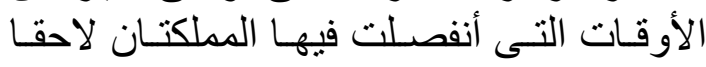

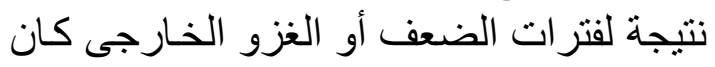

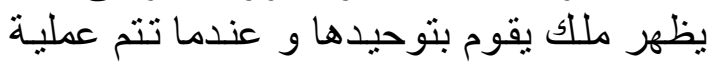

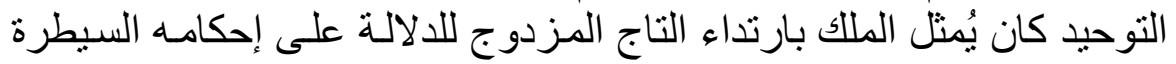

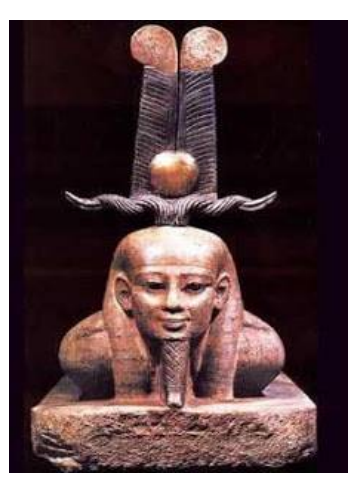

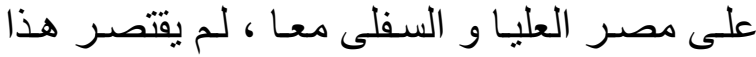

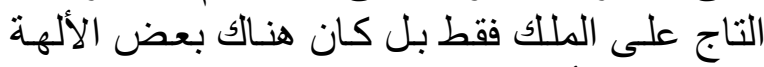

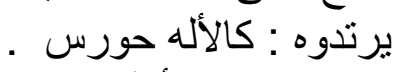

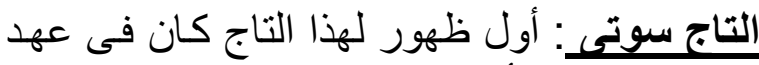

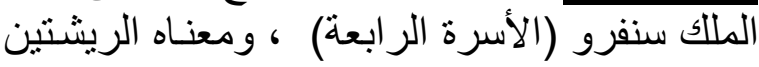

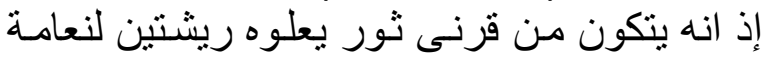

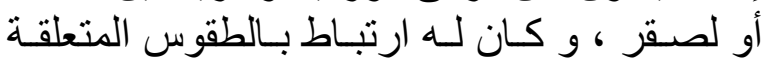
بتولى الملك الحكم . 


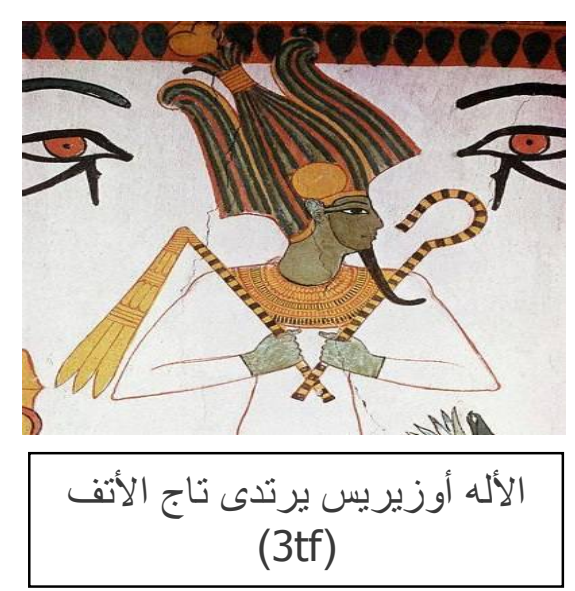

- تـاج الأتف : ظهر في عهد الملك الكا

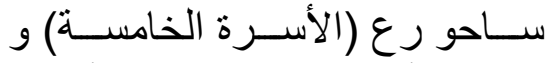
معنى الأسـ

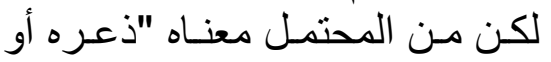

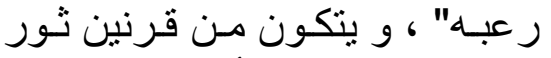

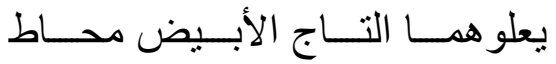
بريشتى نعام ، ويرمز التاج لوحدة الأبط

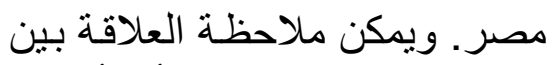
التاج و بعض الالهية كالأله أوزير بلهير

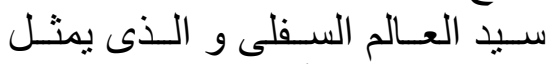

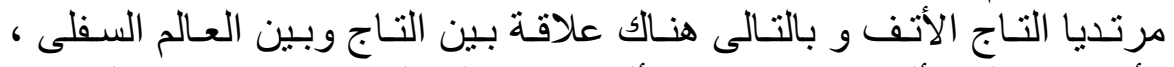

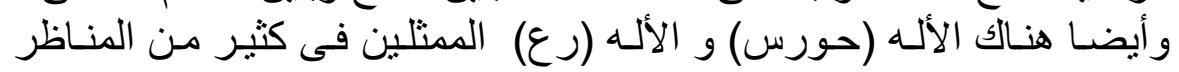
مرتديا هذا التاج.

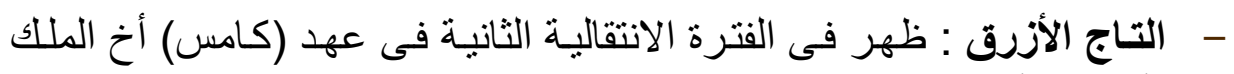

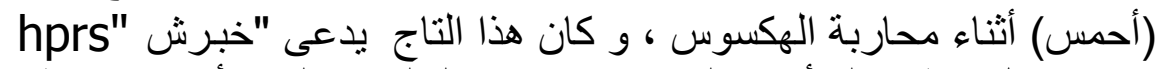

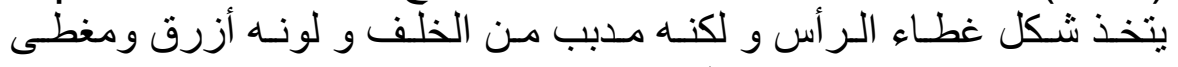

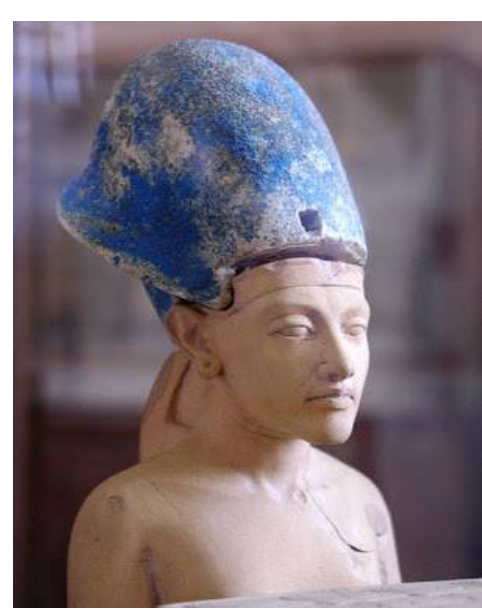

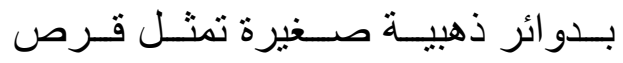

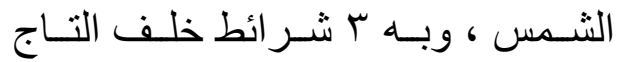

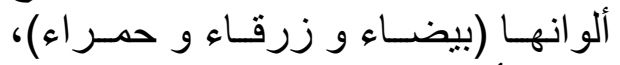

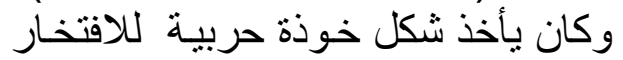

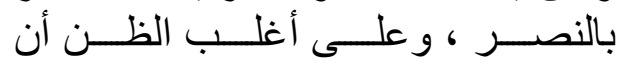

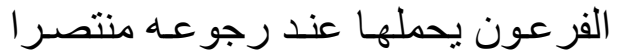

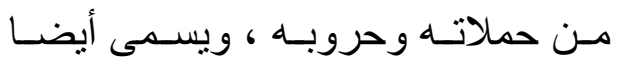

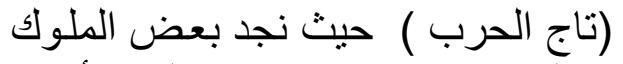

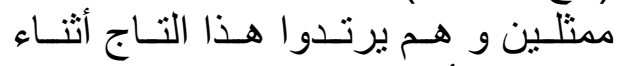

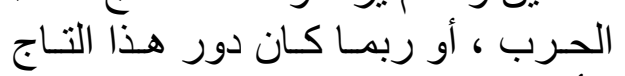

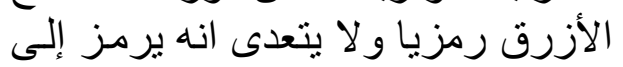

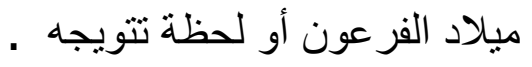


أمثلة للارتداء ملوك البطالمة التيجان الفرعونية:

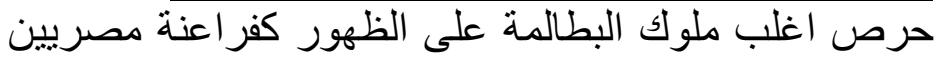

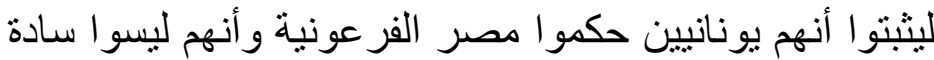

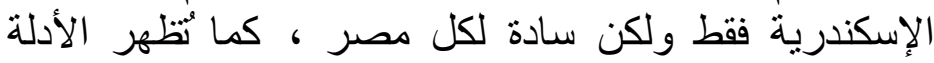
الأثرية ومنها على سبيل المثنال :

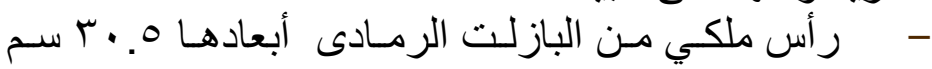

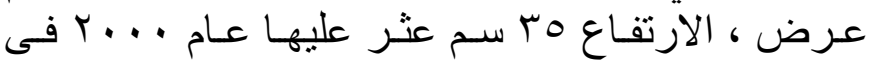

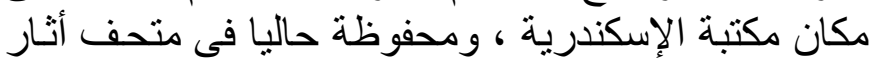

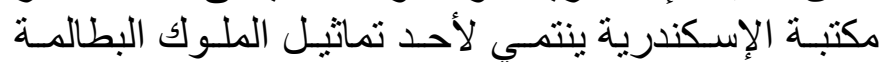

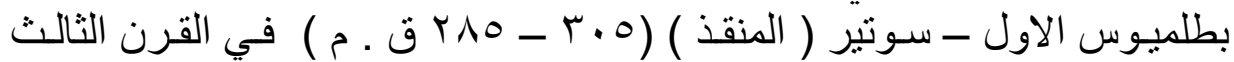

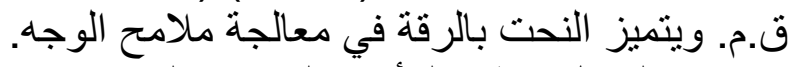

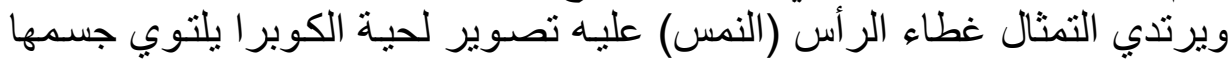
في لفتين كبيرنين. أما الحاجبان فينحدر ان بشدة عند الأركان من العيون التي كانت مرصعة قبلاً .

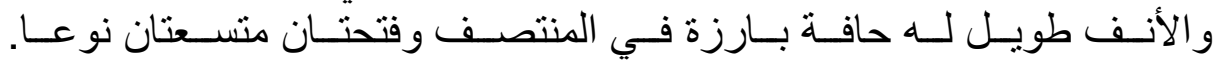

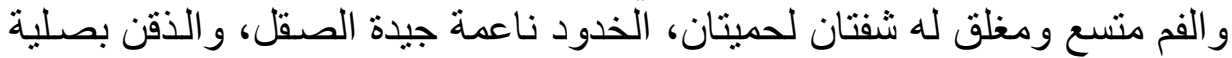

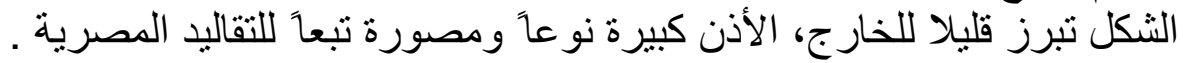

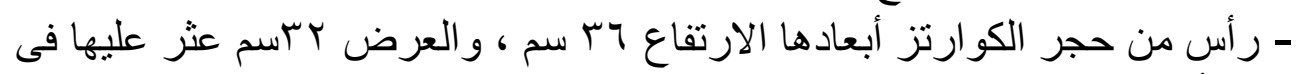

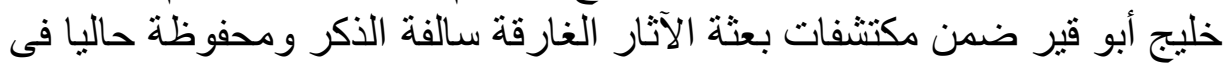

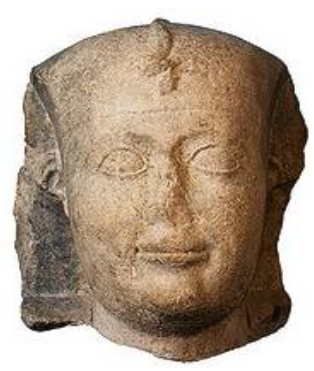

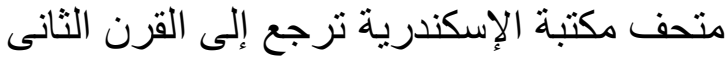

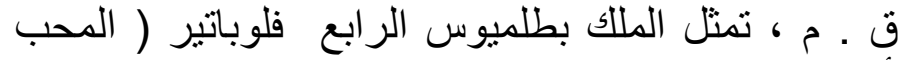

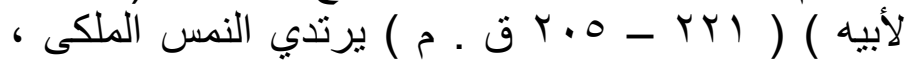

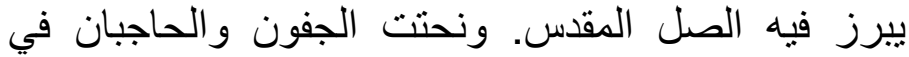

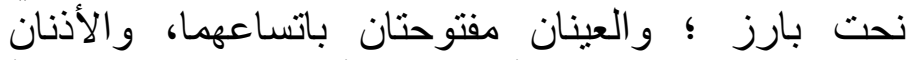

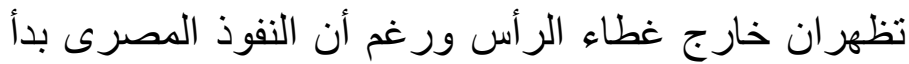

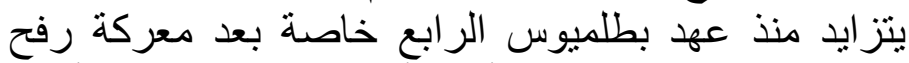

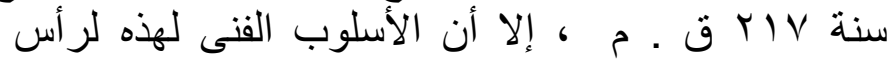
يوضح انه فى تلأك الفترة لم يكن الفن في جمال الفن لفن لفي

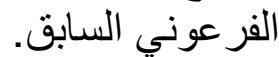

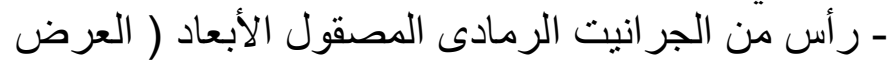

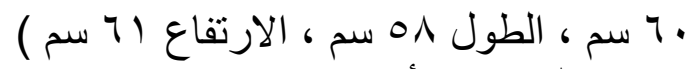

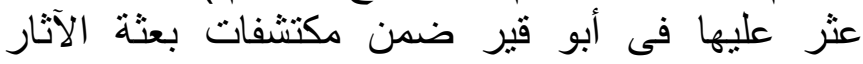

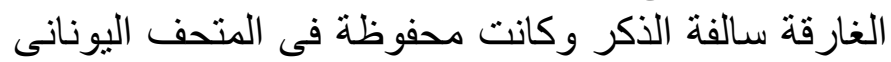
الرومانى ومحفوظة حاليا بمخازن متحف مارينا العلمين . 
دراسات في آثار الوطن العربيَ 1 (1)

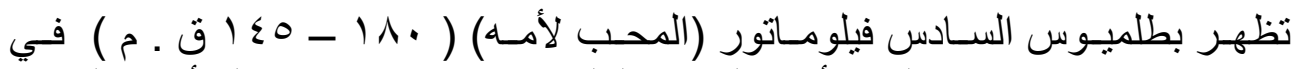

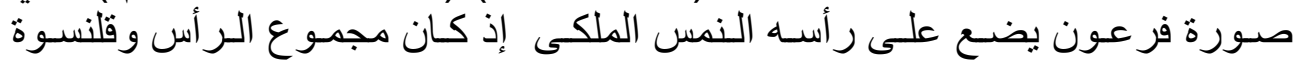

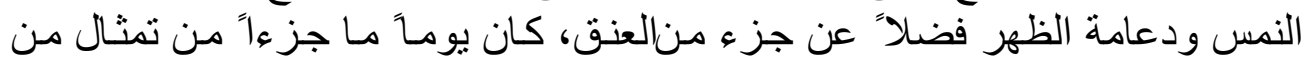
الجر انيت.

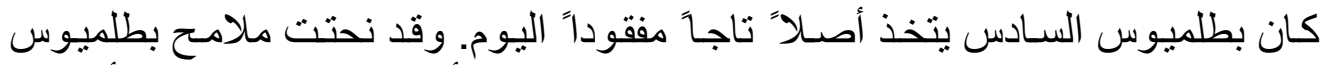

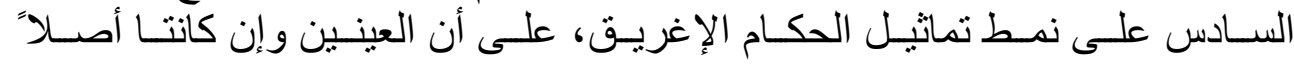

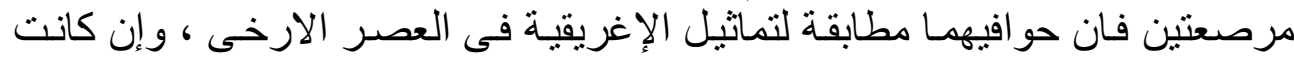

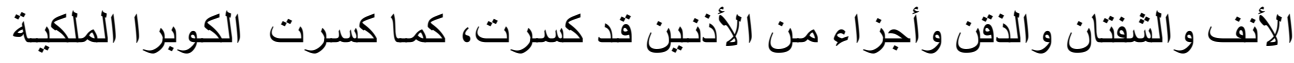
وضاعت رصائع العينين.

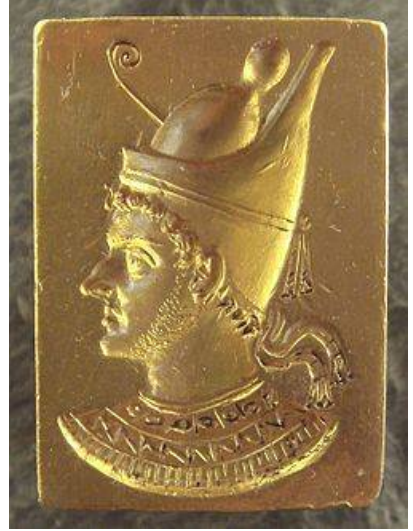

- رسم تخطيطى لبطلميوس السـادس ( فلومـاتير )

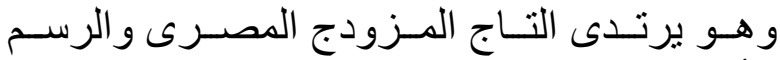

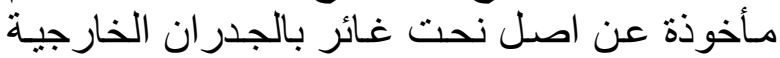

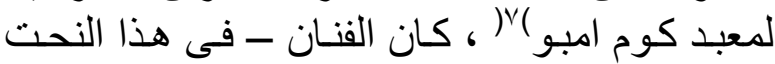

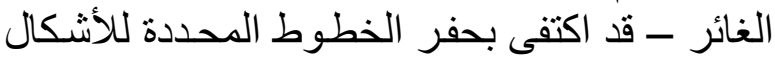

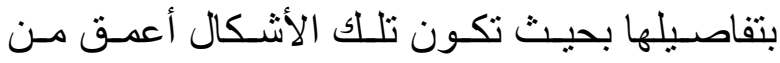

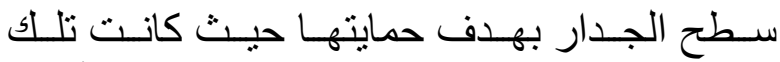

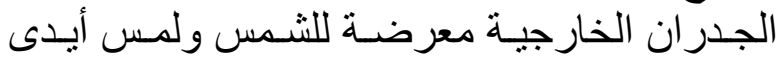

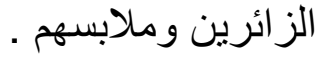

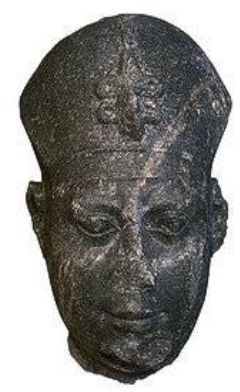

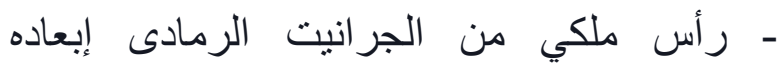

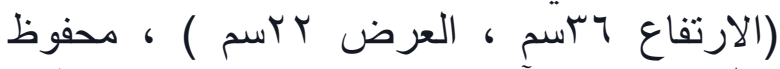

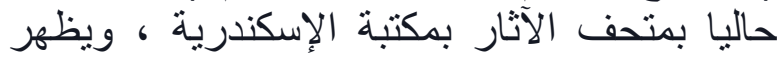

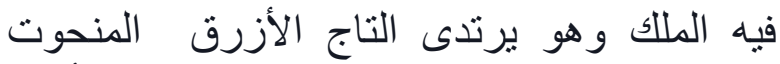

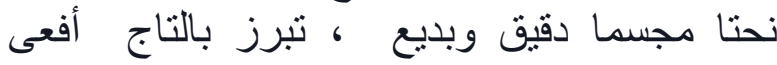

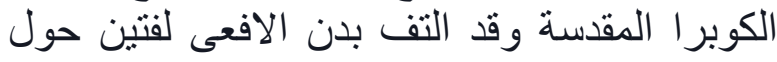
نفسها .

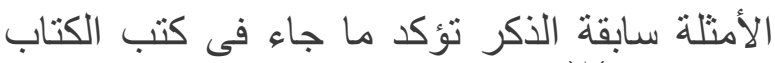

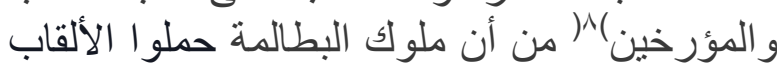

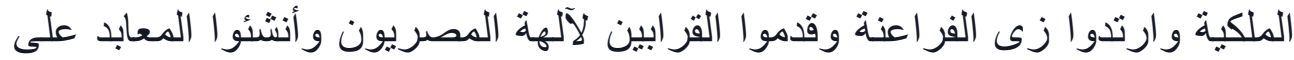

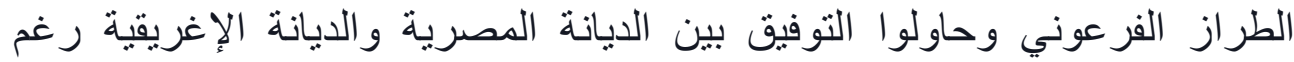
احتفاظهم بهويتهم وشخصيتهم . الطورئ

7 - Gauneron, H., ( Le Temple d'Amada ), Cairo , 1913 , p.p 133 - 136

8 - Sharpe, Samuel, The History of Egypt Under the Ptolemies, (London 1838 ), Kessinger Publishing's Reprints, USA 2007, 
فتللك الأمثلة نلاحظ أنها تنتمي إلى التاريخ السياسي و التقافي للعـالم اليوناني الفتي،

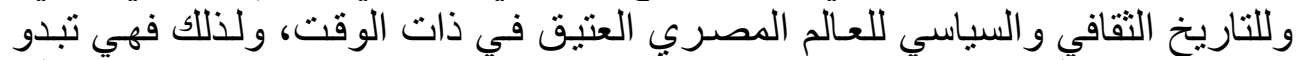

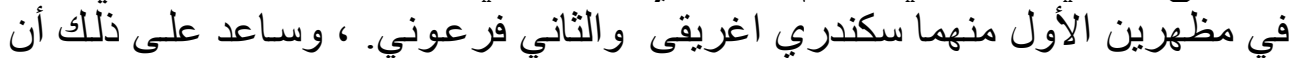

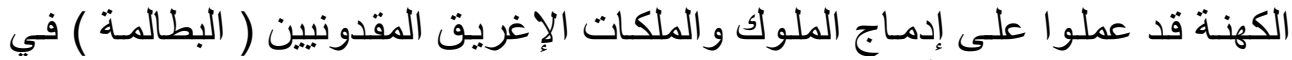

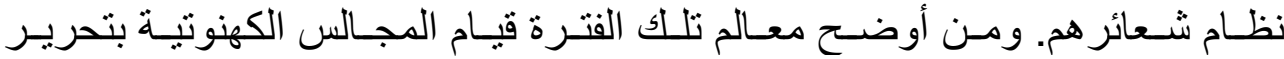

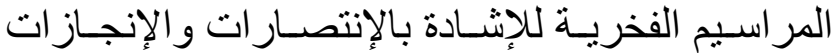

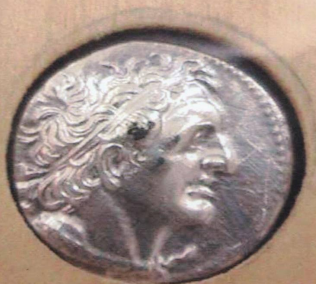

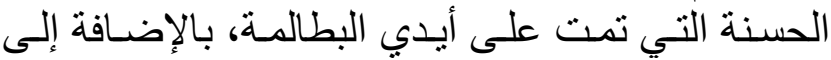

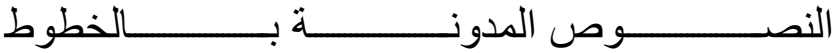
الهيرو غليفية و الديموطيقية و اليونانية..

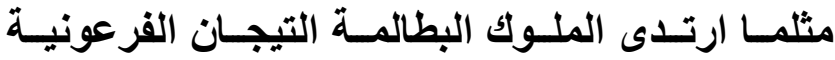
ارتدوا أيضا التيجان اليونانية التى كان من اشهرها

\section{عملة لبطميوس الأول بتاج دياديما} تاج دياديما(9) " Diadema " : وهو اسم يونانى

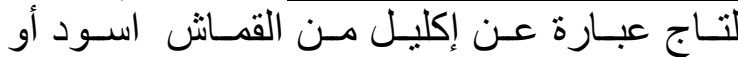

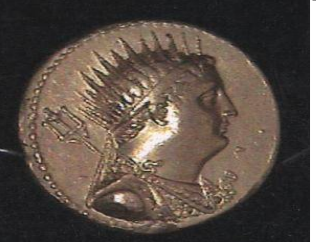

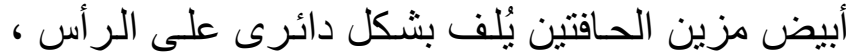

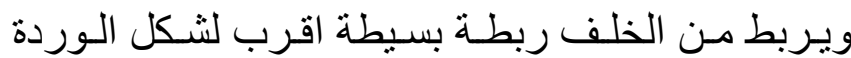

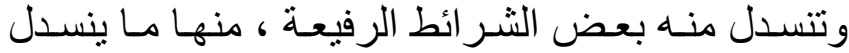

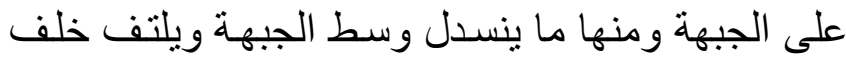

عملة لبطلميوس الثالث يرتدى تاج هليوس

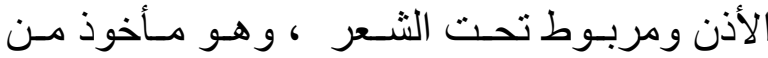

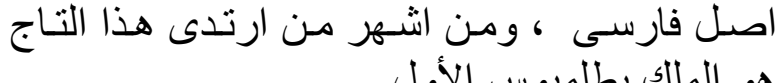

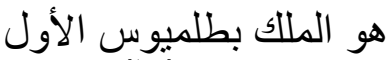

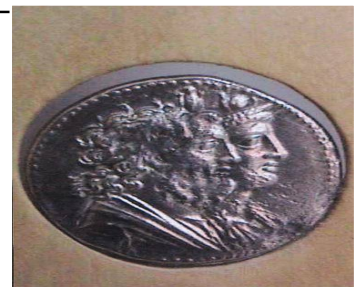

عملة لبطلميوس الرابع بتاج على زئه

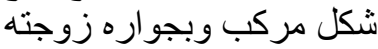

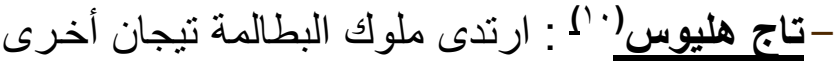

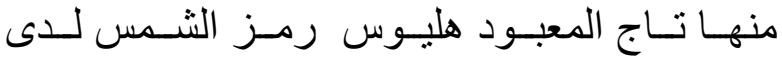

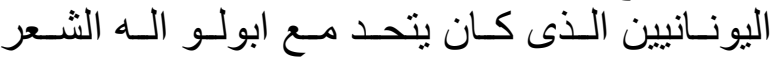

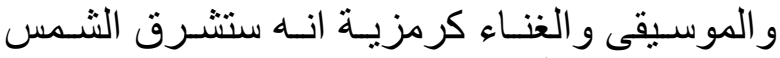

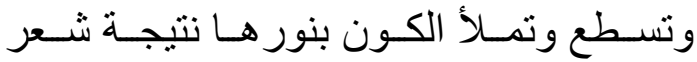
و غناء وموسيقى ابوللو ـونساج هليوس عبارة

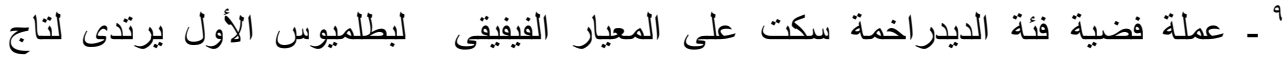

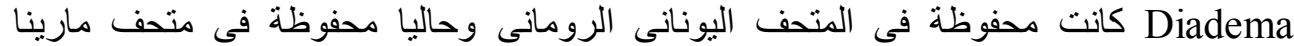

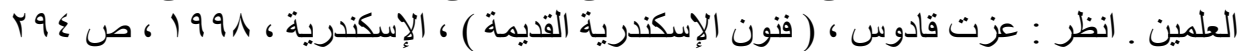

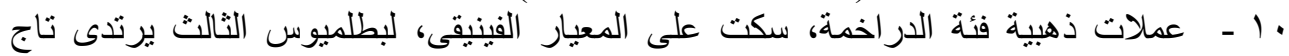

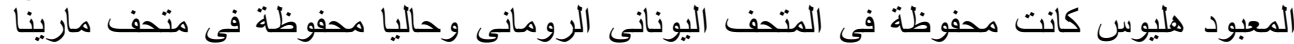

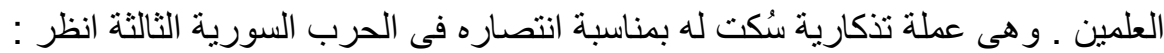
Svoronos , J,N. ( TA NOMI $\sum$ MATA TOY KPATOY $\sum$ T $\Omega$ N IITO $\Lambda$ EMAISN I-IV ), Athen , $1904-1908$ ), ( trans by Regling, K. ), no. 1117, pl.36, figs 1-2 
دراسات في آثار الوطن العربيَ 1

عن تاج عالى كبير ذو شعب مشعة تتسـاقط أربطته على مؤخرة الر أس ويُصنع

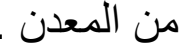

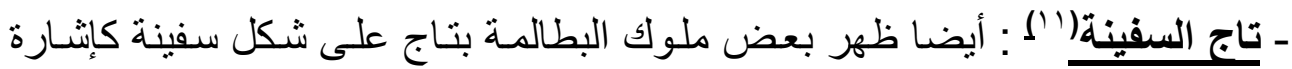

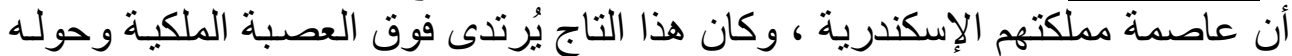

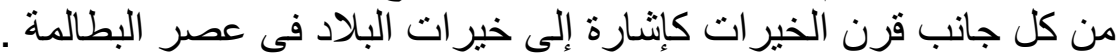

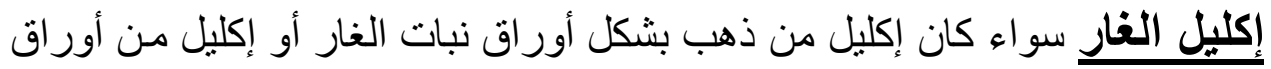

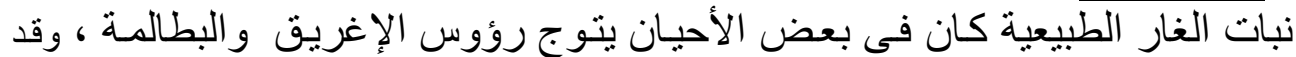

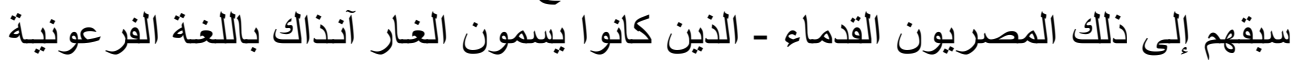

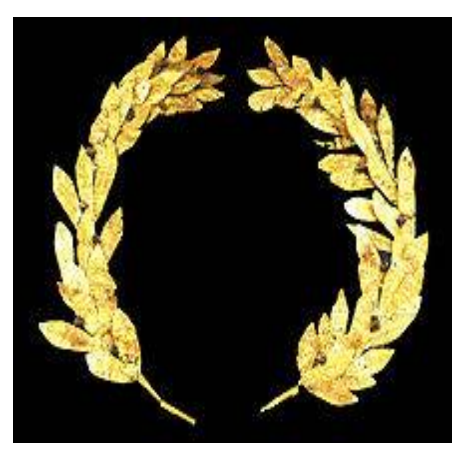

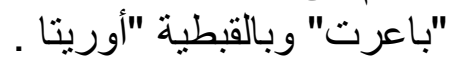

$$
\text { متحف قبرص صن الذهب بشكل أوراق الغار محفوظ فى }
$$

إكليل من أوراق الغار الطبيعية

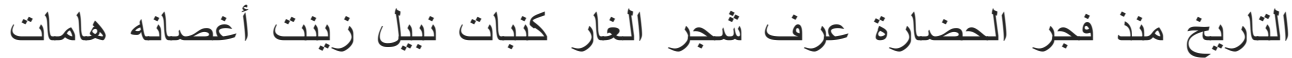

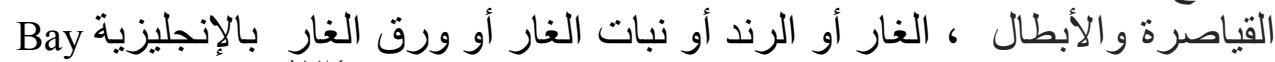
Laurel

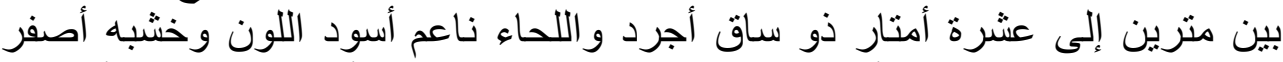

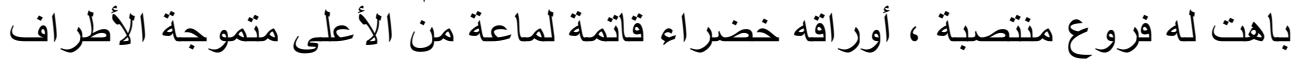

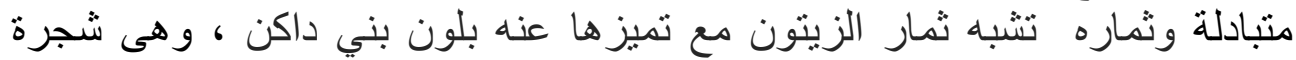

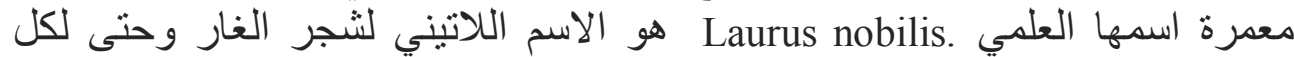

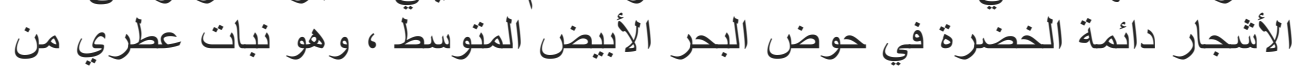

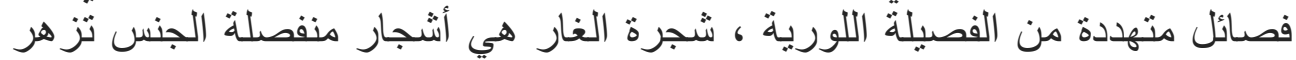

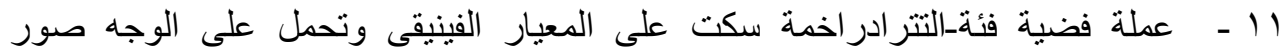

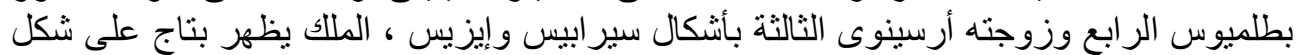

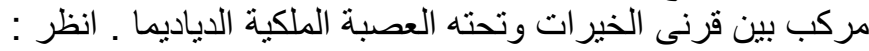
Heckel,W. and Sullivan,R.,'Ancient Coins of the Graeco-Roman world", (Press,1984), Fig.43

12 - Reisner, The Early Dy. Cemeteries of Nage- el Deir , Part 1 , t II , p. 16 , 19, \&22 
في منتصف ابريل والأشجار المذكرة لا تعطي ثمارً” وتكون الثمار بشكل عناقيد

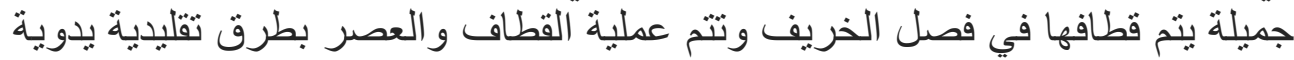

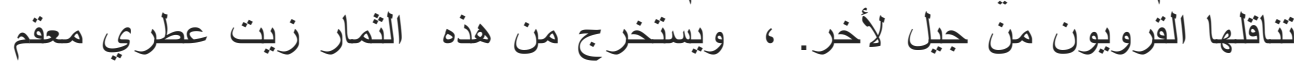

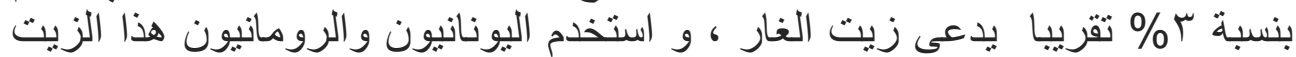

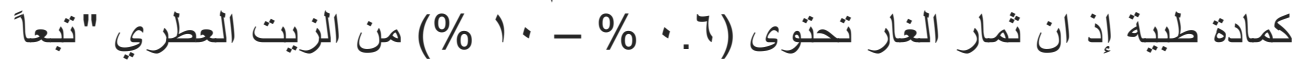

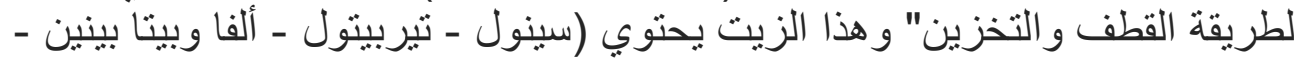

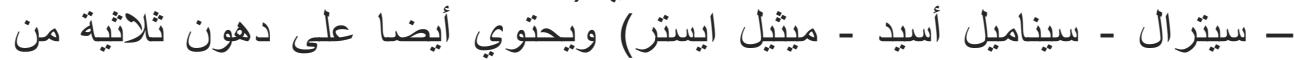

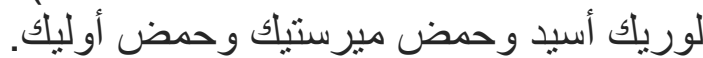

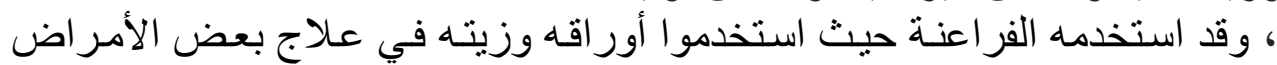

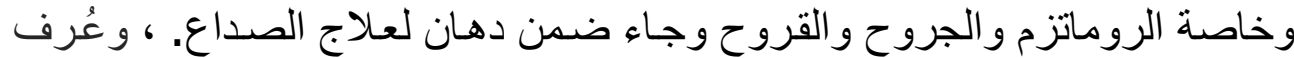

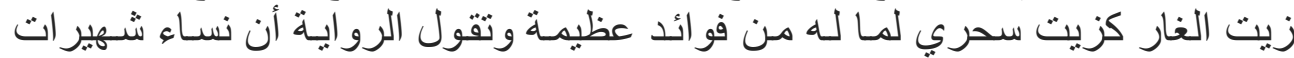

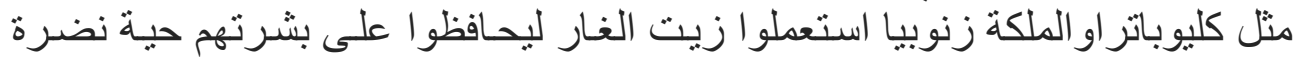
و على عافية شعر هم وصحته.

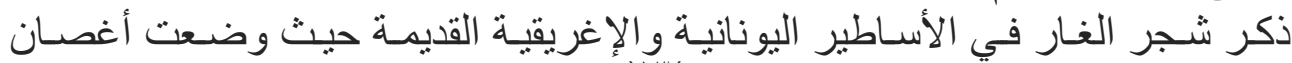

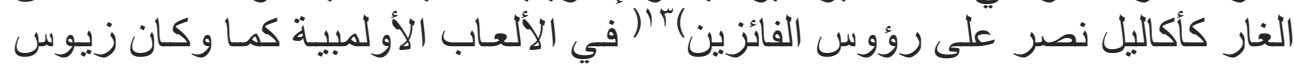

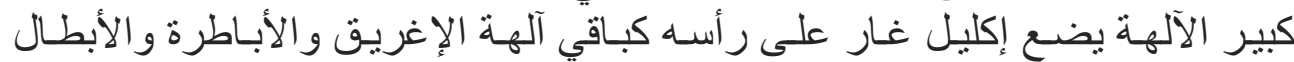

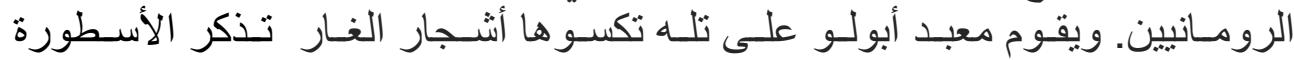

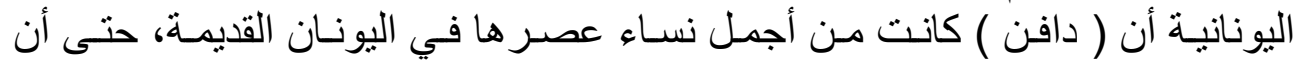

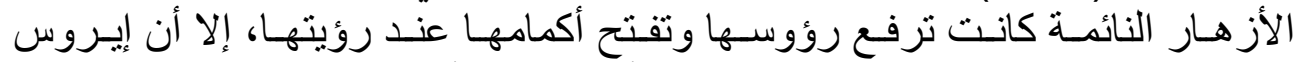

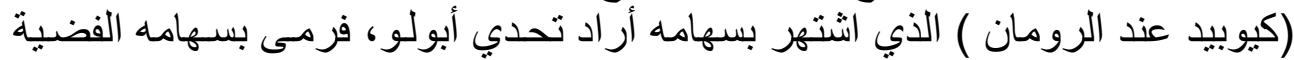

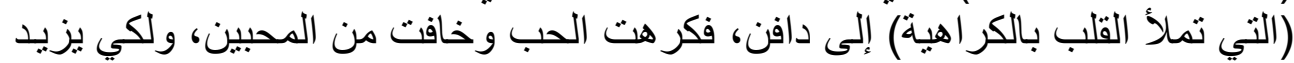

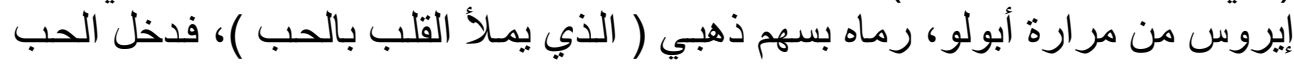

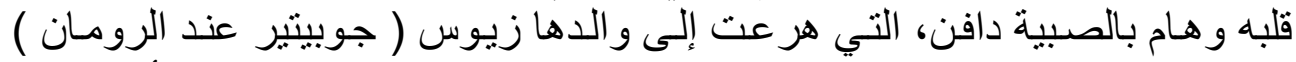

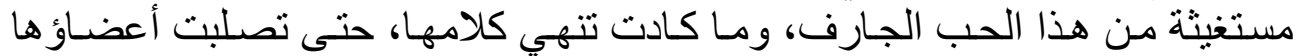

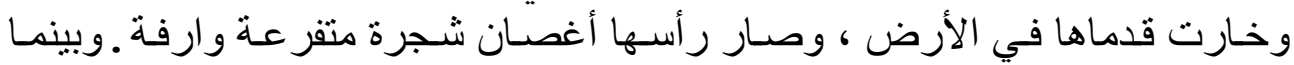

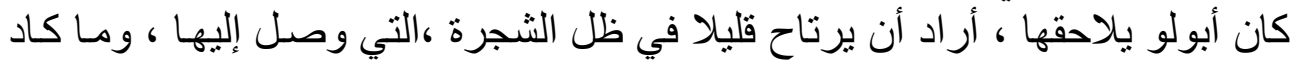

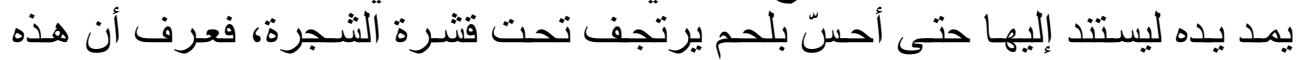

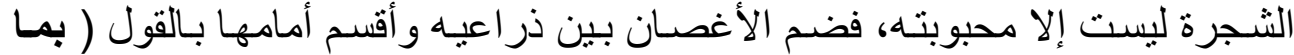

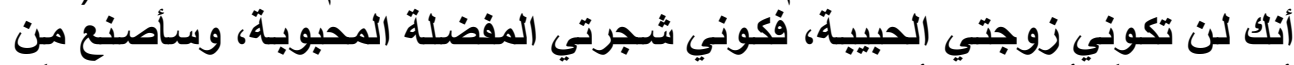

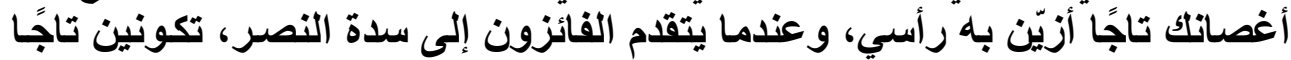

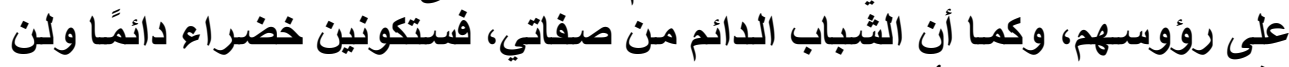

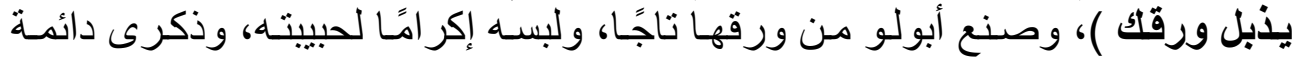

13 - Andrew Stewart: Greek Sculpture, ( Yale, 1990.) 
دراسات في آثار الوطن العربيه 1

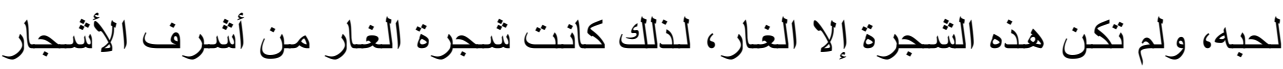

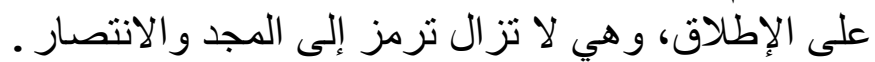

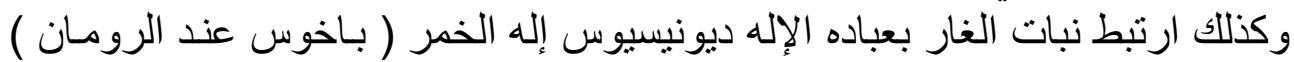

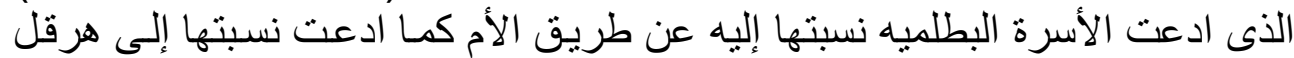

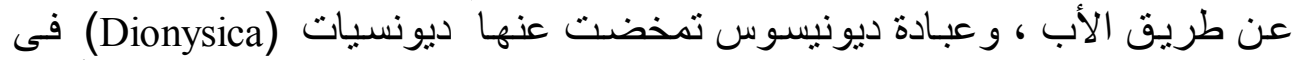

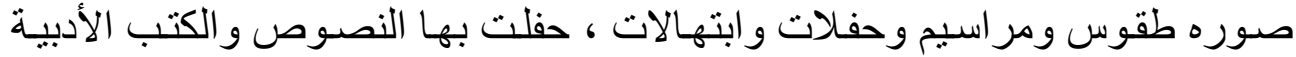

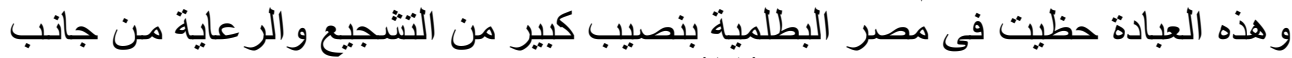

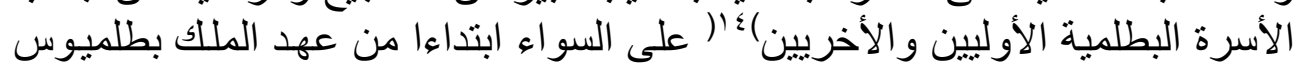

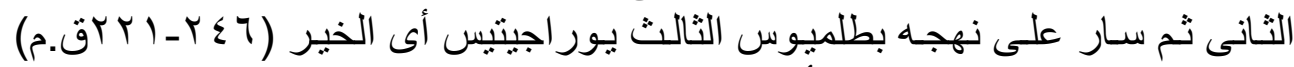

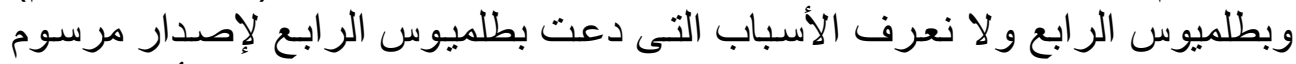

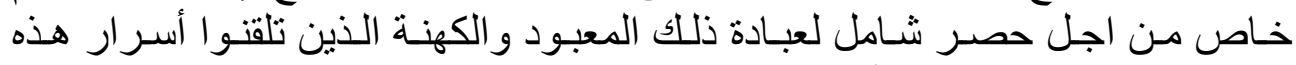

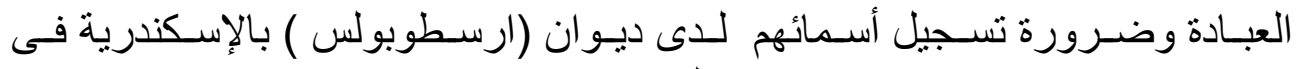

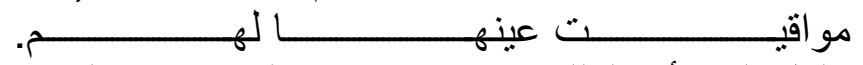

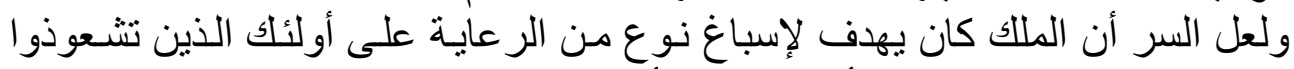

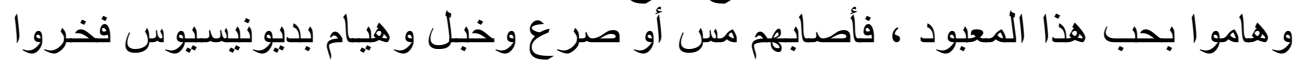

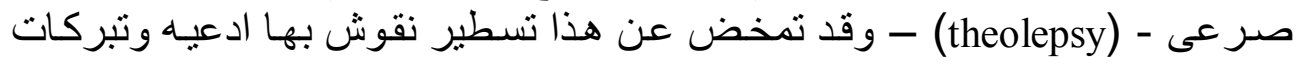

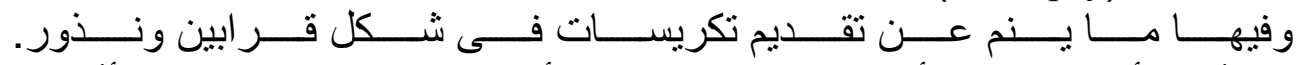

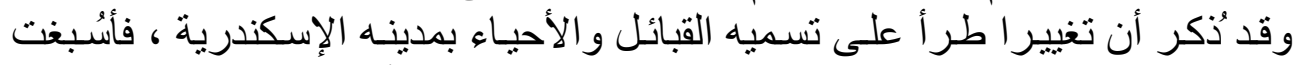

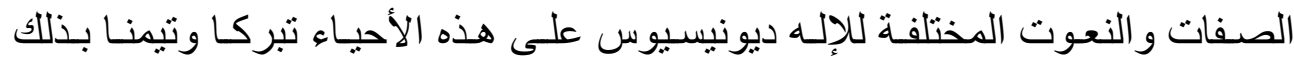

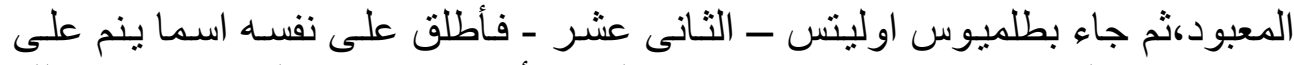

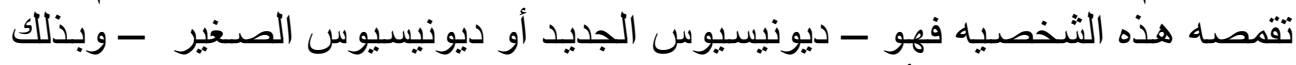

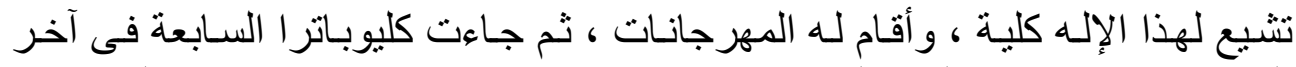

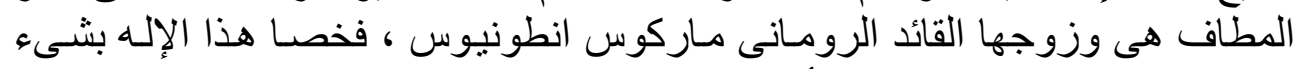

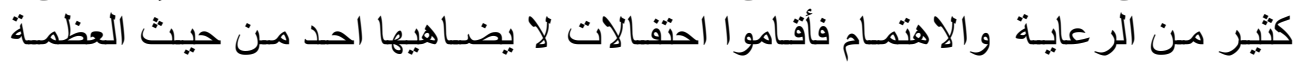

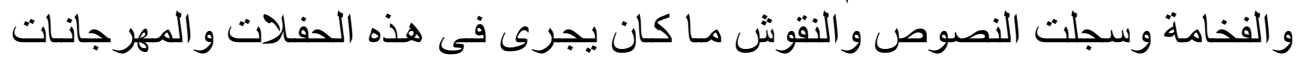

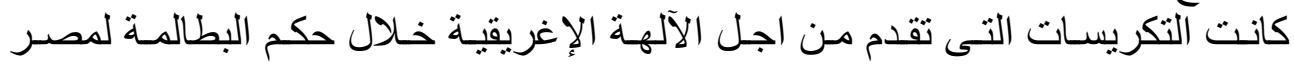

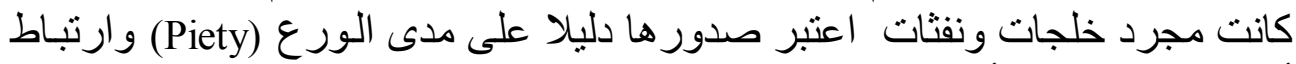

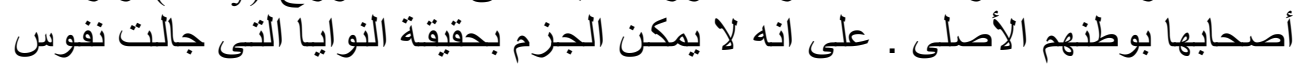

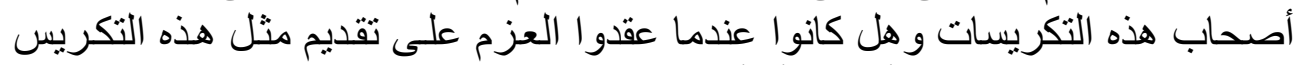

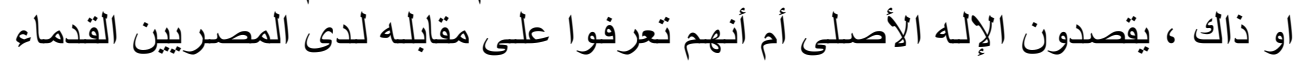
كوسيلة للتقرب إليهم ، ففى حاله اسكلبيوس مثلا وهو الإله الـه الثفاء عند اليونان ، كانوا

14 - Holbl, Gunther, A History of The Patolemaic Empire, Routledge, London \& New York 2007 , 
دراسات في آثار الوطن العربيجا

يفكرون فى مقابله عند المصريين القدماء وهو امحتب ـ وفى حالله ديونيسيوس كانو اليرا

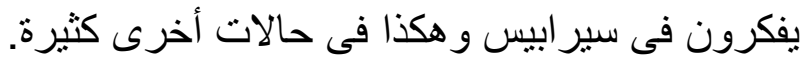

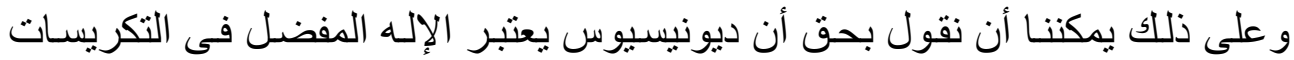

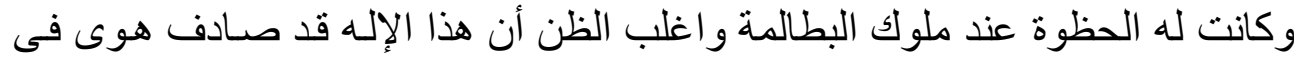

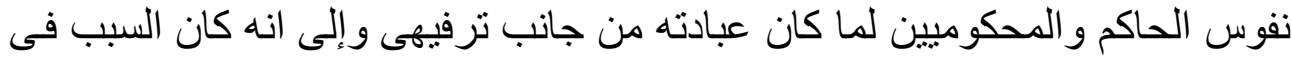

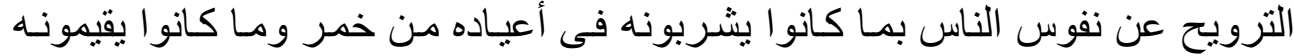

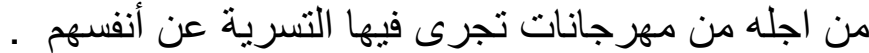

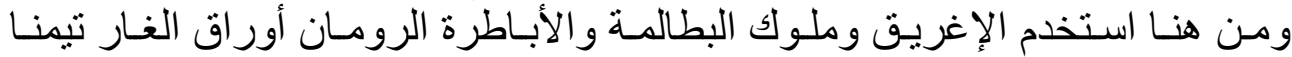

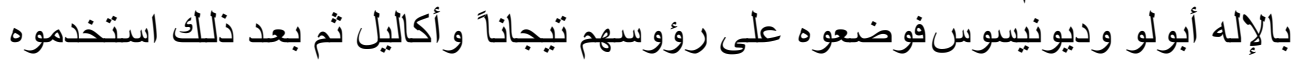

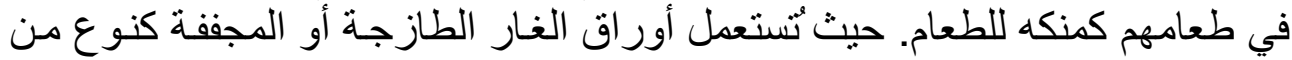

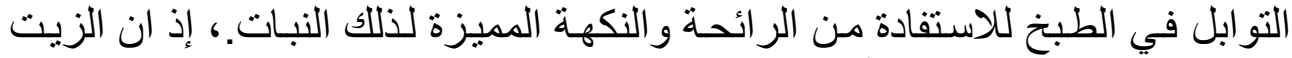

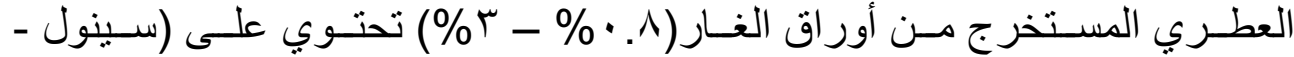

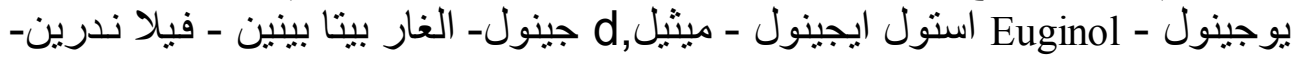

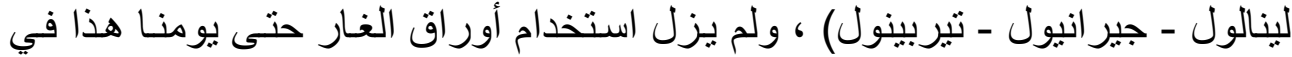

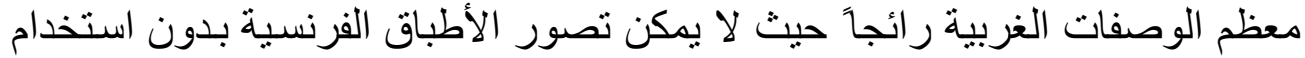

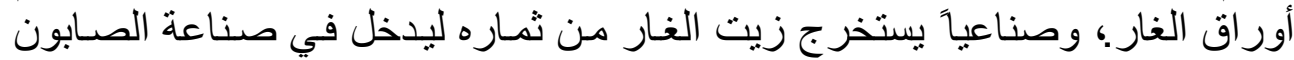

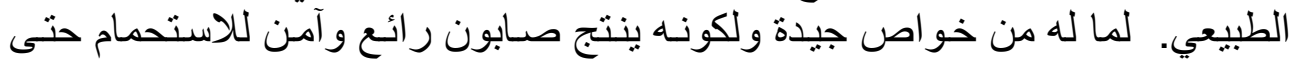

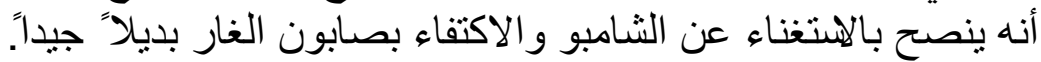

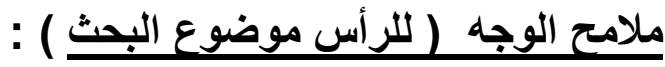

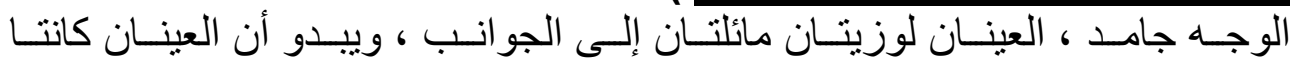

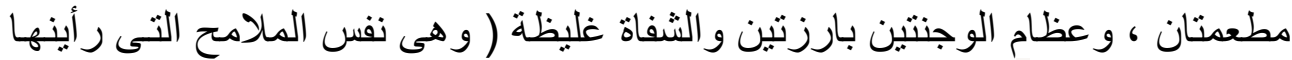

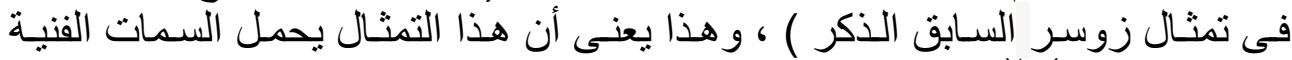

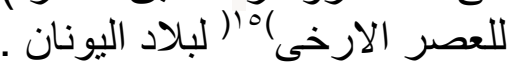

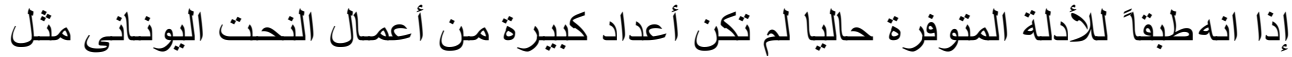

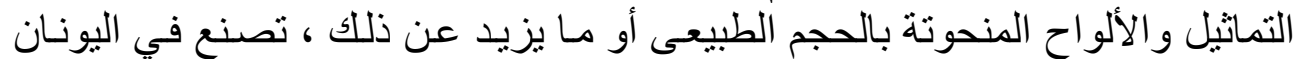

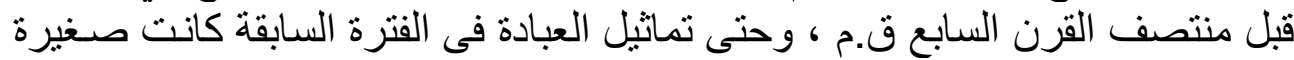

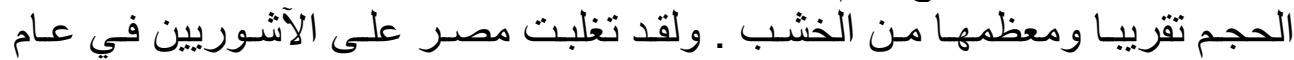

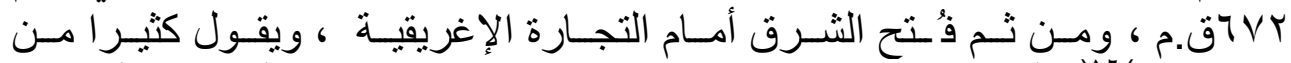

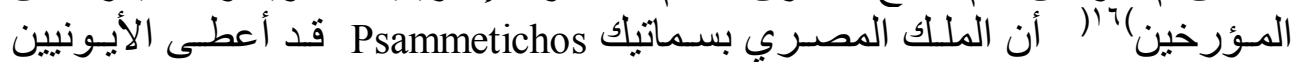

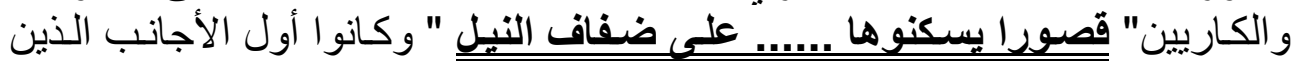

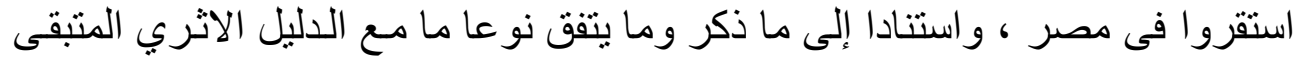

15 - Gagarin, Michael, Elaine Fantham (contributor), The Oxford Encyclopedia of Ancient Greece and Rome, Volume 1, Oxford University Press, 2010

$$
17 \text { - هيردوت : الكتاب الثانى ؛ الجزء الأول ؛ ص ؟ ؟ }
$$


دراسات في آثار الوطن العربيَ 1

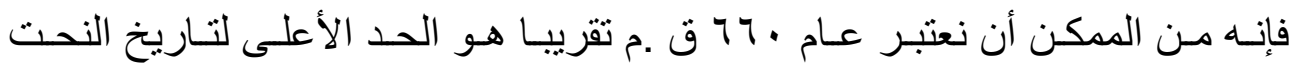

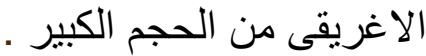

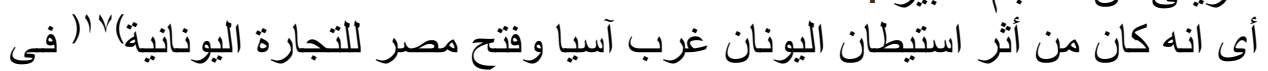

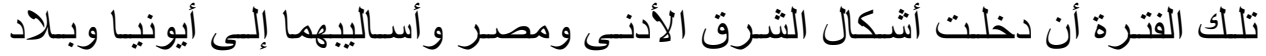

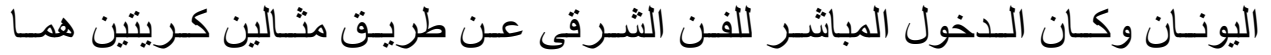

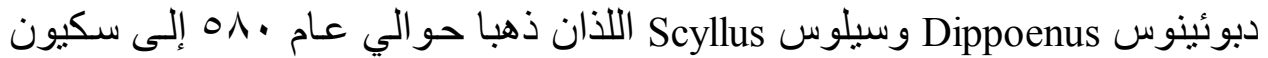

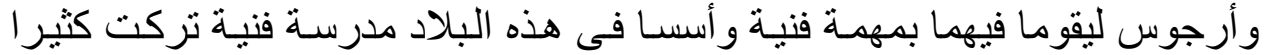

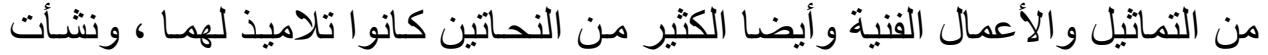

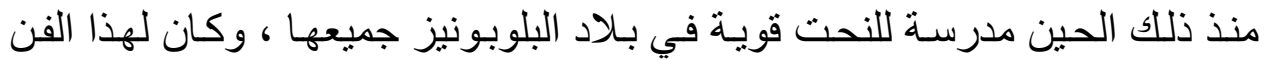

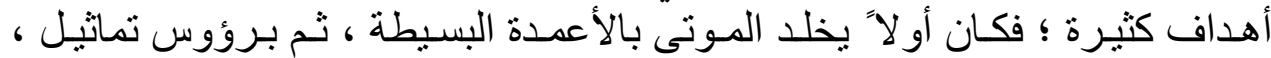

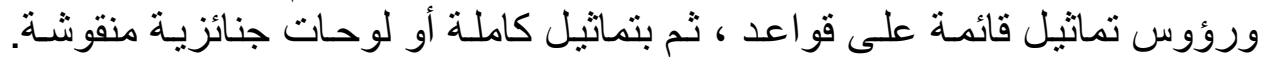

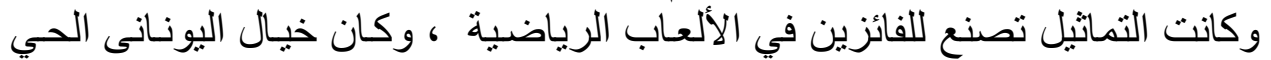

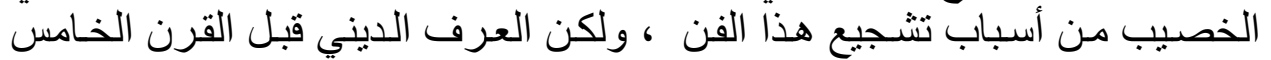

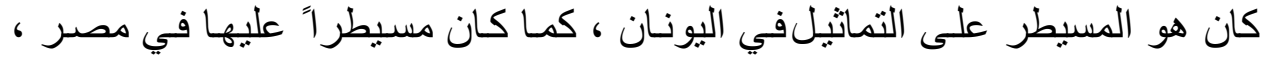

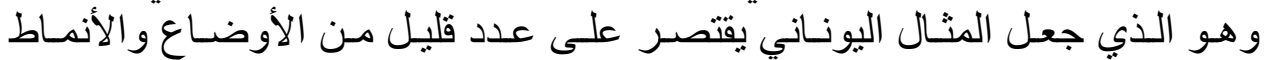

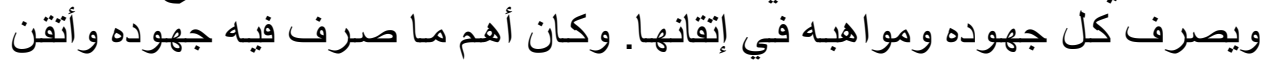

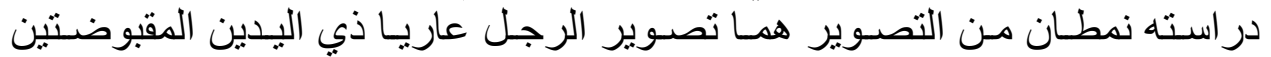

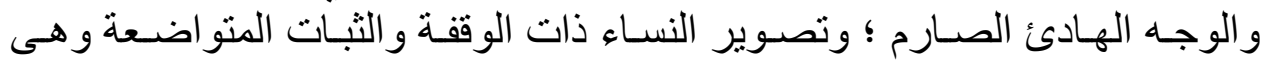

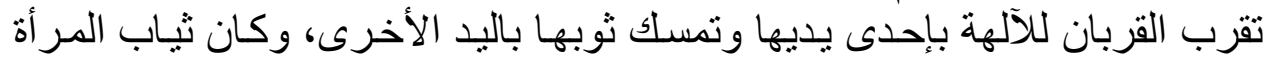

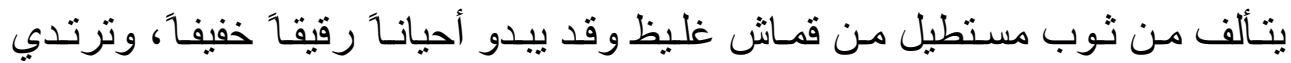

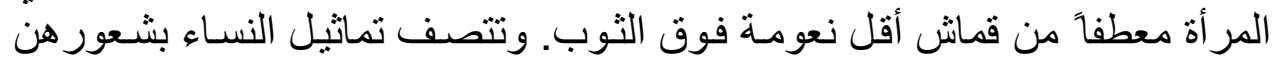

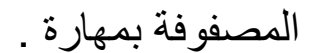
وقد لجأ بعض النحاتين إلى نحت الأطر اف و الر أس مستقلة قبل تجميعها سو اء كان

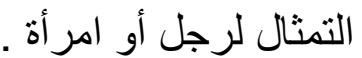
هذا النمطان لتماثيل الرجل و المر أة جعلا التماثيل في كثير من آثنار النحت اليونانيـة

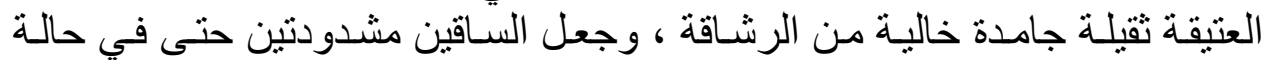

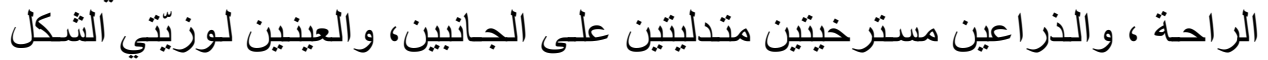

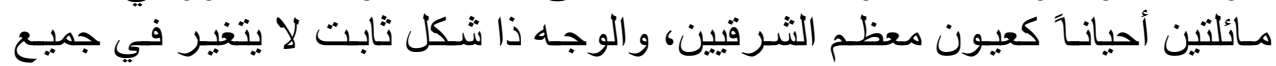

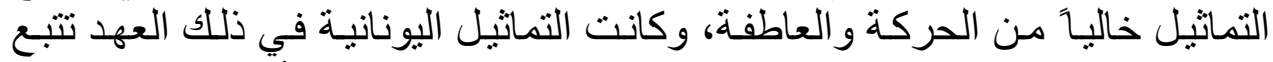

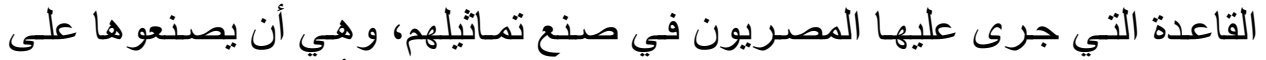

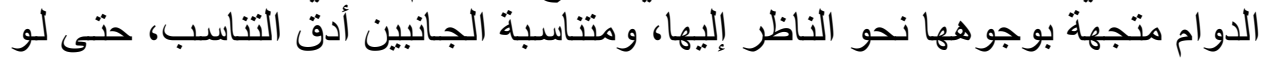

17 - El período micénico se caracteriza en arquitectura por los robustos muros y palacios de aparejo ya ciclópeo, poligonal y medio escuadrado y por las tumbas de cúpula falsa la cuales se hallan diseminadas por las regiones de Grecia y mar Egeo. 


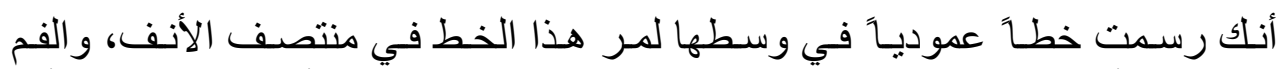
و السرة وأعضاء التناسل لا يحيد عن ذللك قيد شعرة إلى اليمين أو اليسار ، و لا يتأتز ووضعه بحركة الجسم أو سكونه.

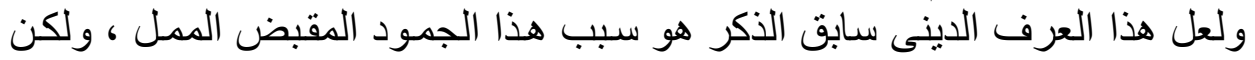

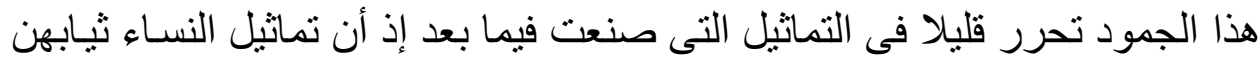

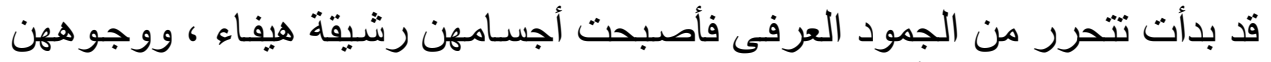

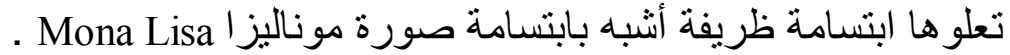

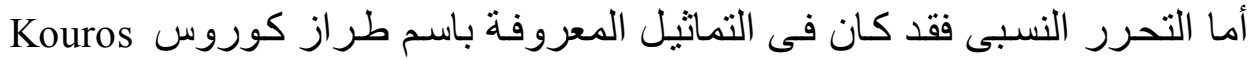

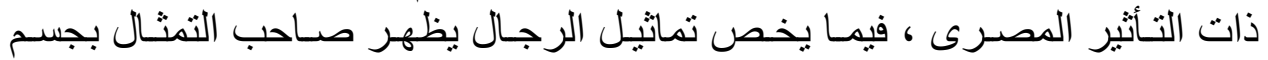

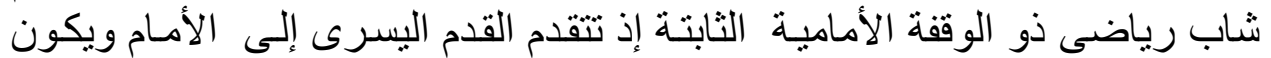

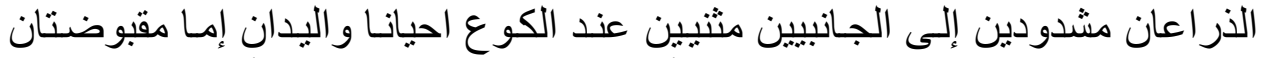

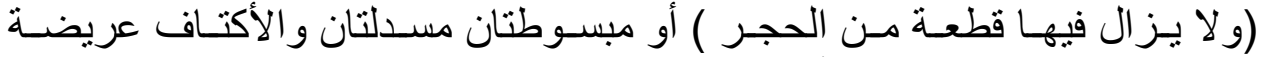

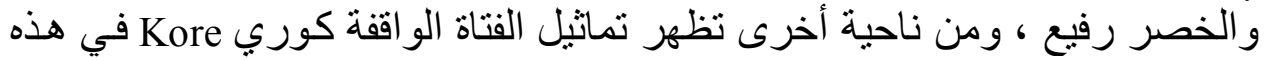

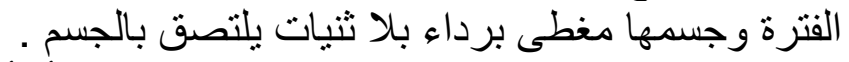

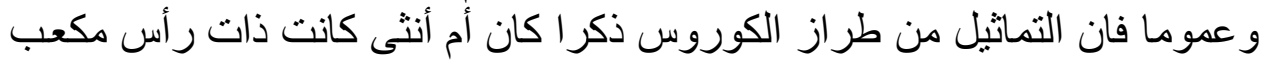

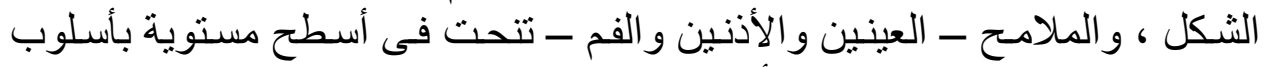

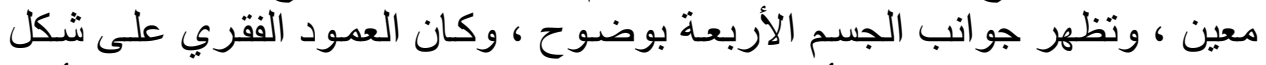

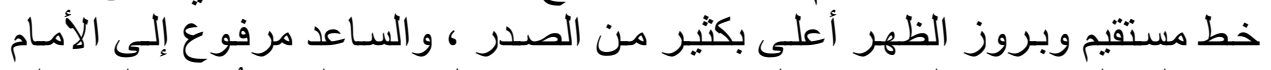

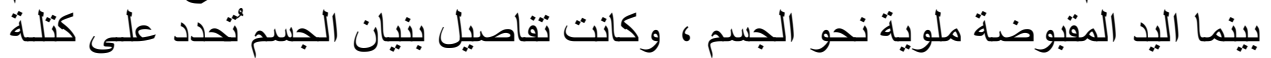

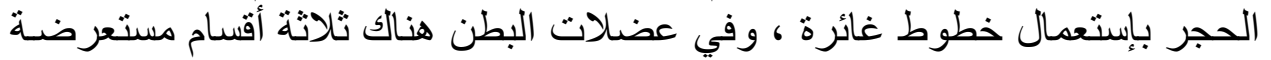

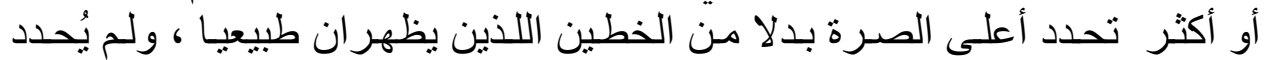

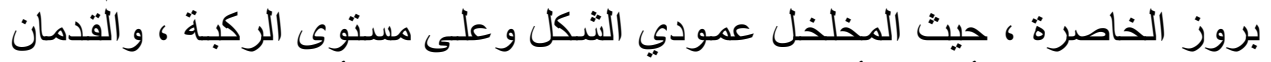

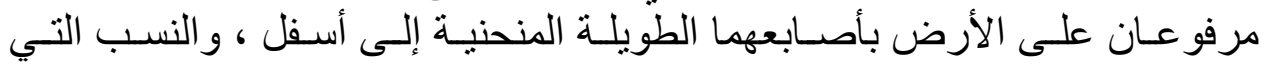

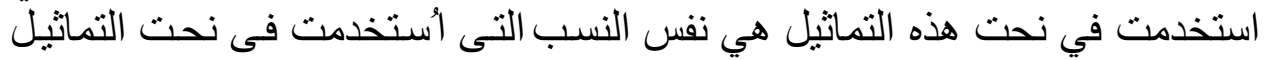

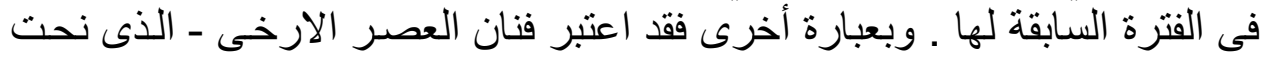

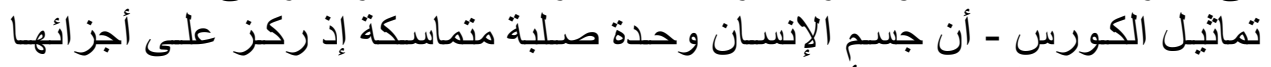

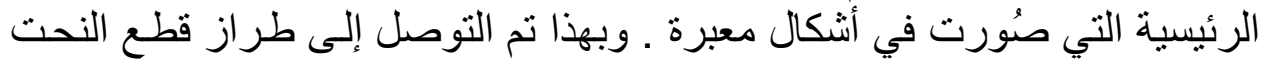

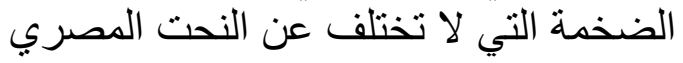


دراسات في آثار الوطن العربيَ 1

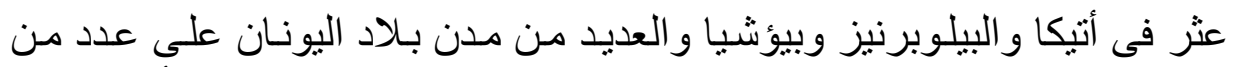

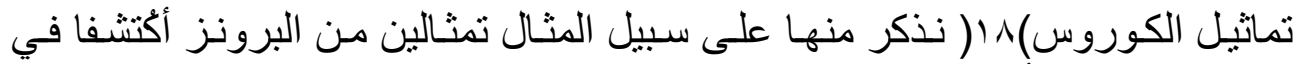

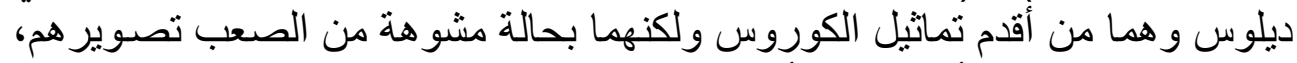

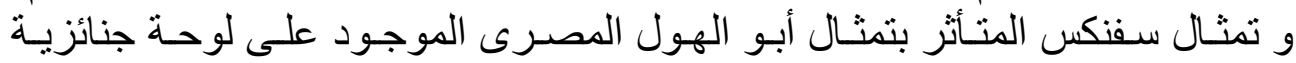

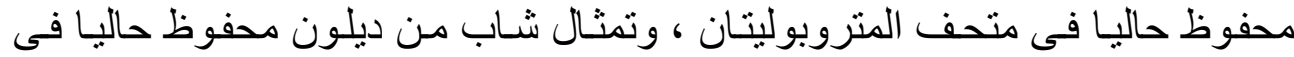

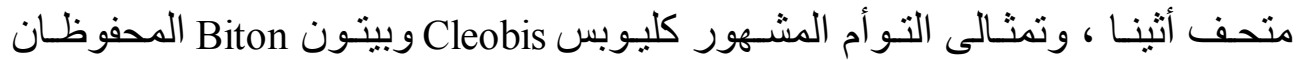

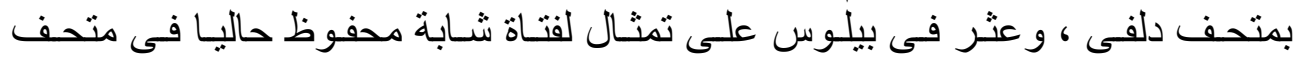

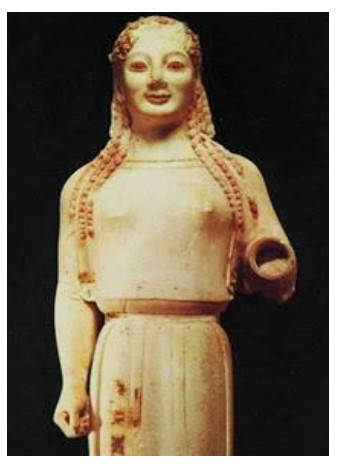

شابة البيلوس متحف

الاكروبول فى أثنينا

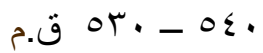
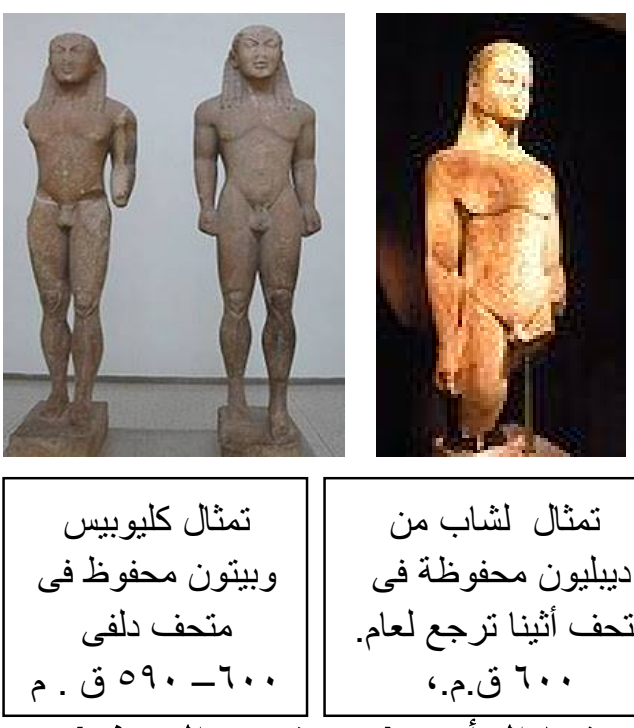

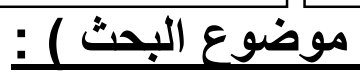

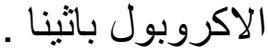

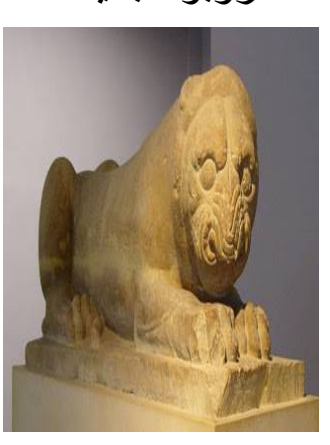

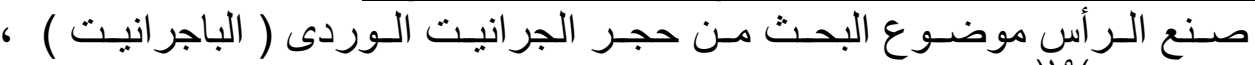

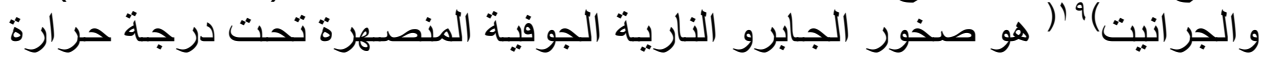

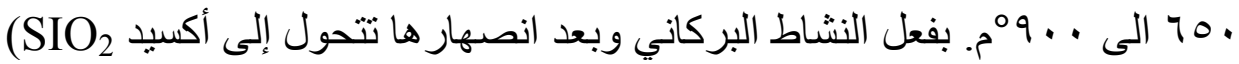

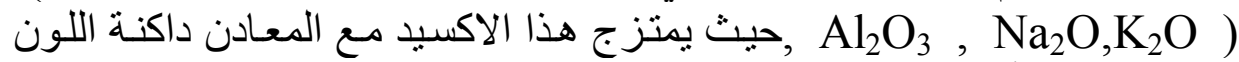

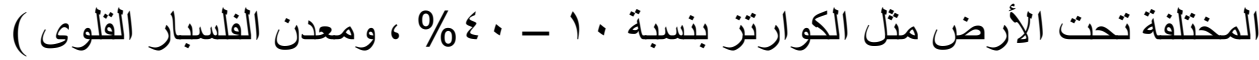

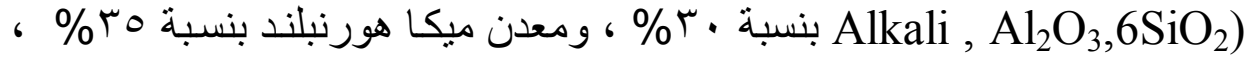

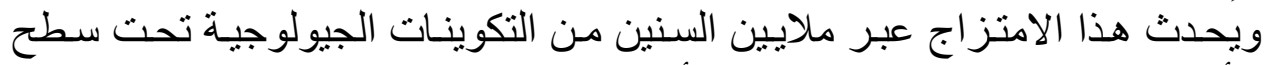

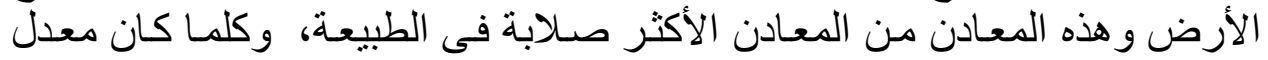

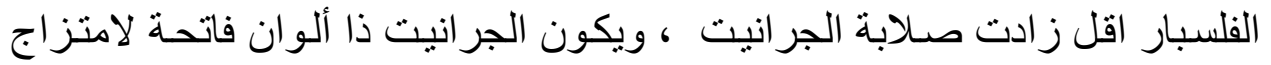

18 - John Boardman: Greek Sculpture :The Archaic Period, 1978.

19 - مجمع اللغة العربية ، ( مجموعة المصطلحات العلمية والفنية التي أقرها المجمع ) ،، المجلد

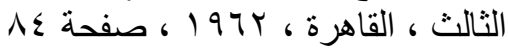


دراسات في آثار الوطن العربيه 1

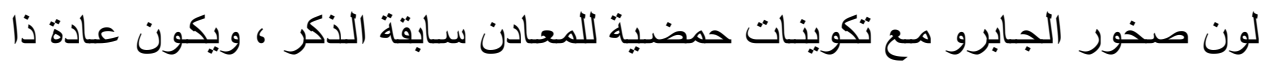

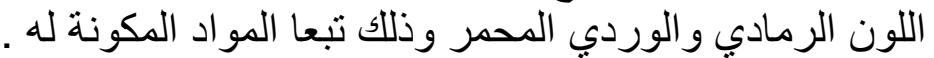

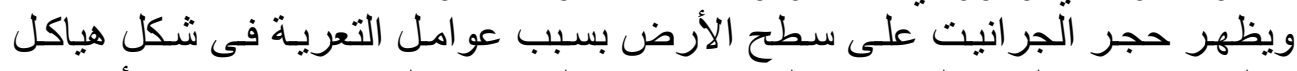

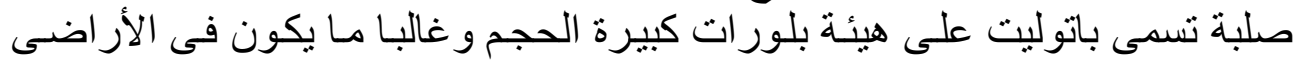

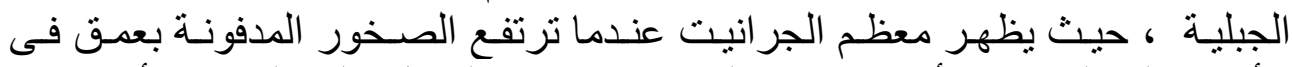

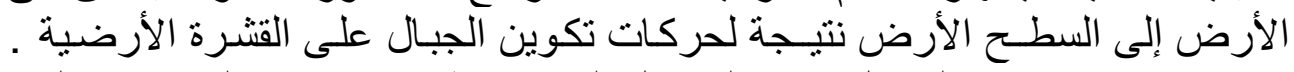

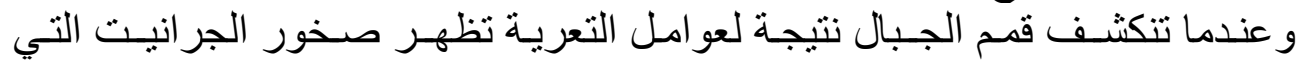

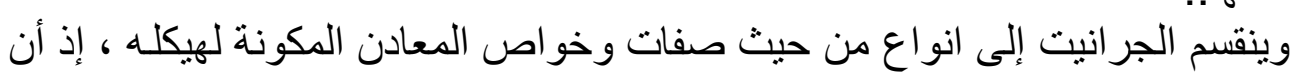

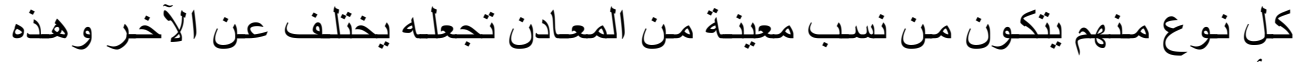
- جر انيت وردي الباجر انيت : يتكون من حبوب سميكة يُستخرج من محاجر جيدة ، و

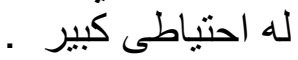
- جر انيت وردي غيلاطلار انيت : يوجد في الطبيعة على شكل مسحوق يستخرج من

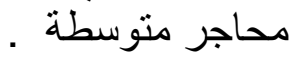

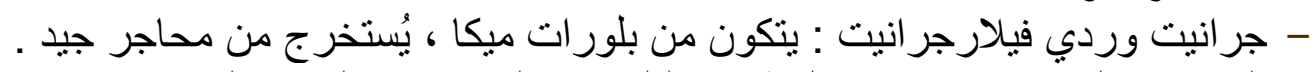

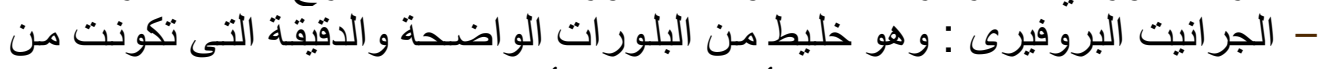

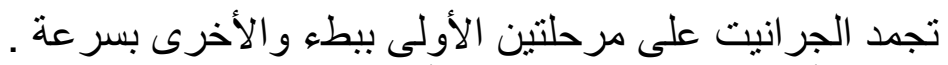
وكل هذه الأنواع تستخدم فى جميع أنواع التطبيقات والات والتشطيبات ، ويتميز الجر انيت تذكرنا مادة الجر انيت الوردى بما كان يصنعه مثنالو أثنينا فى القرن السـادس فقد كانوا

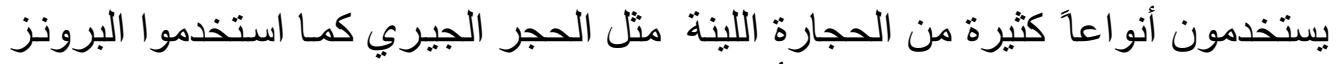

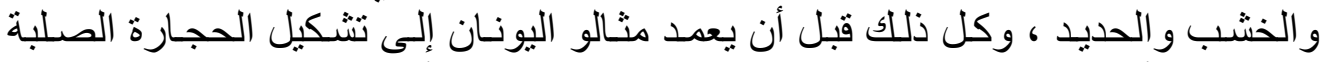

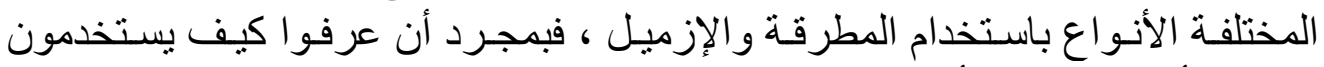

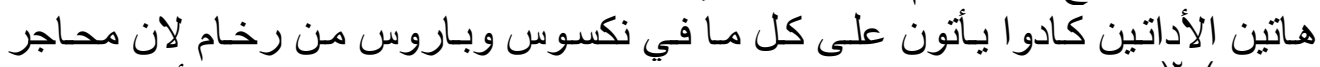

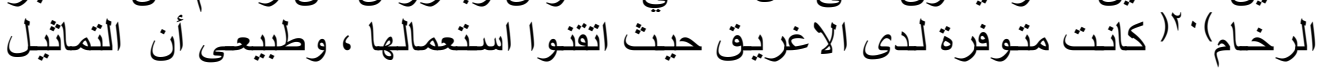

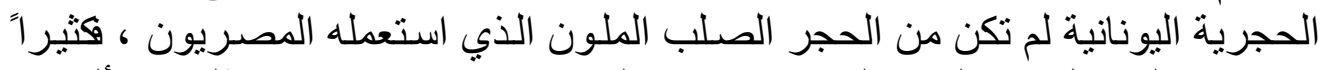

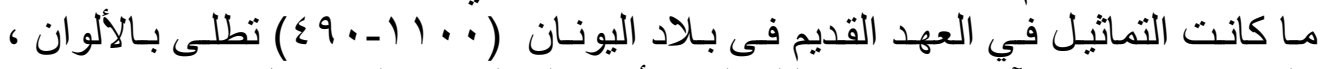

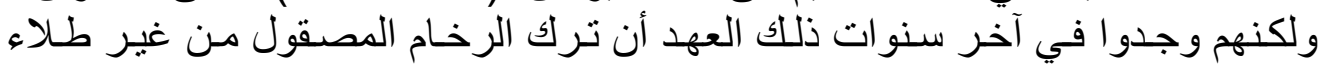

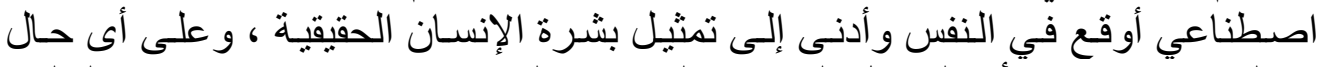

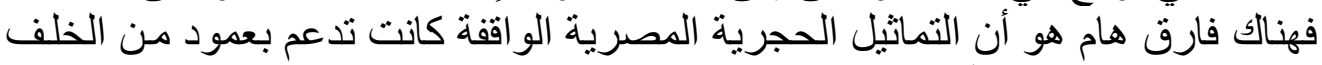

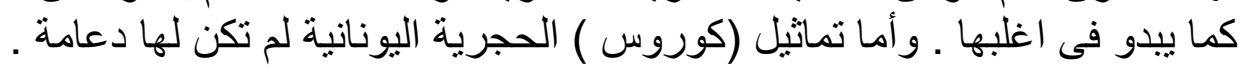

${ }^{20}$ - Andrew Stewart: Greek Sculpture, Yale, 1990 


\section{* الملكك ( صاحب الر أس موضوع البحث ) :}

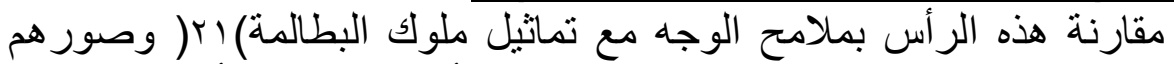

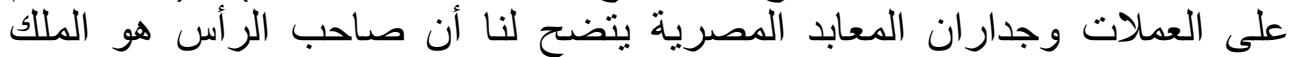

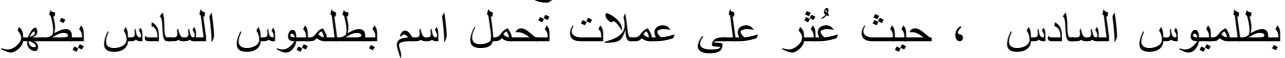

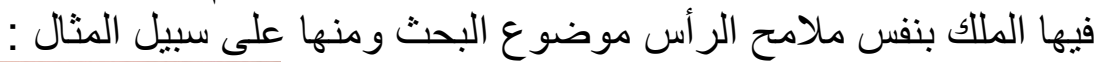

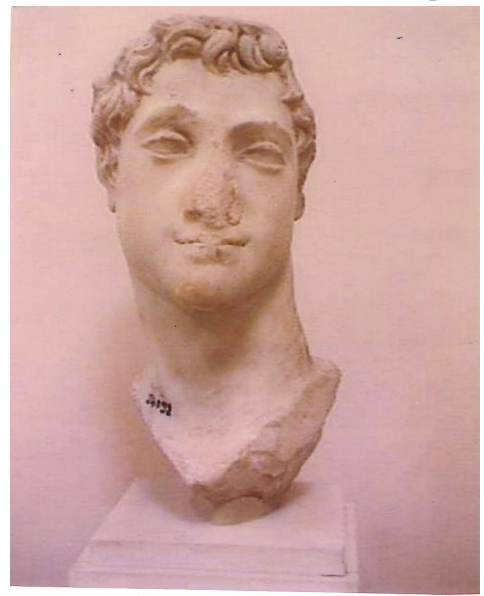

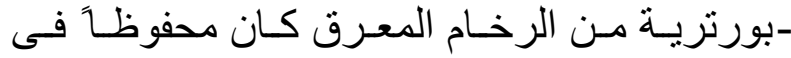

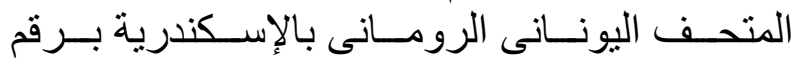

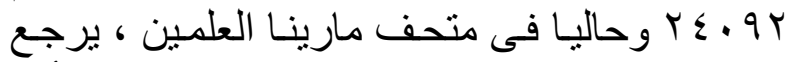

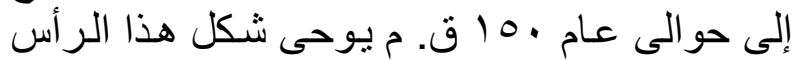

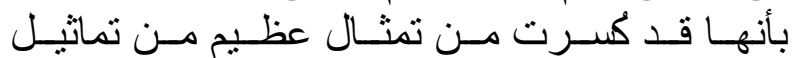

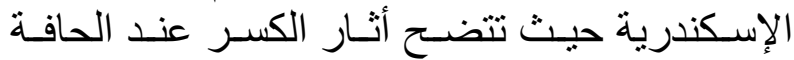

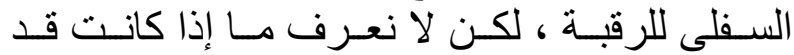

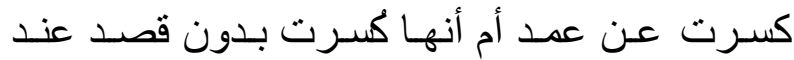

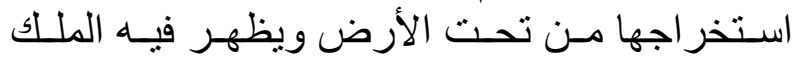

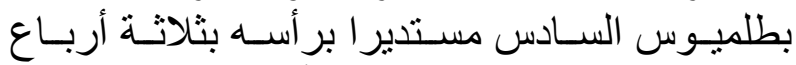

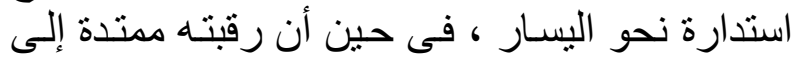

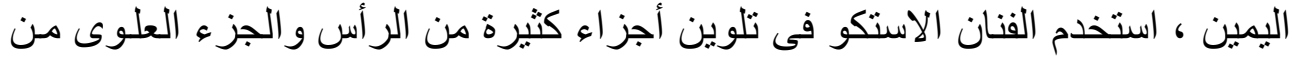

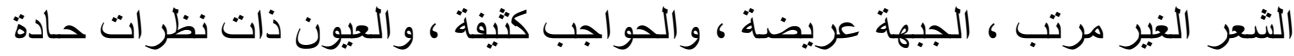

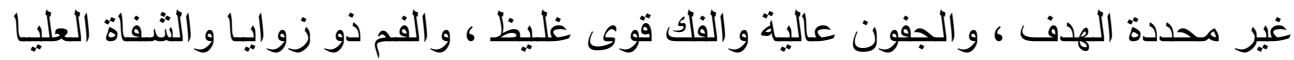

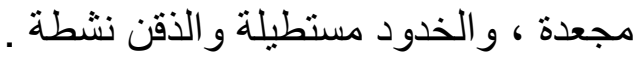

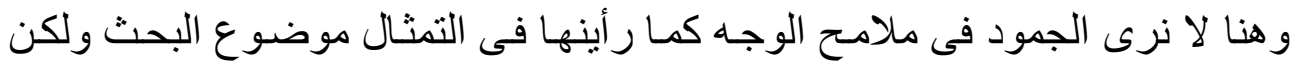

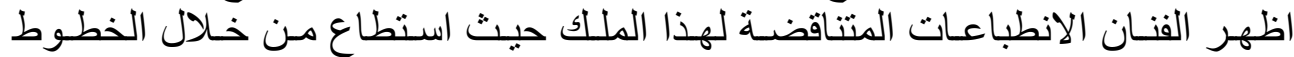

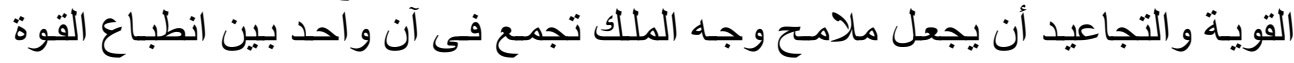

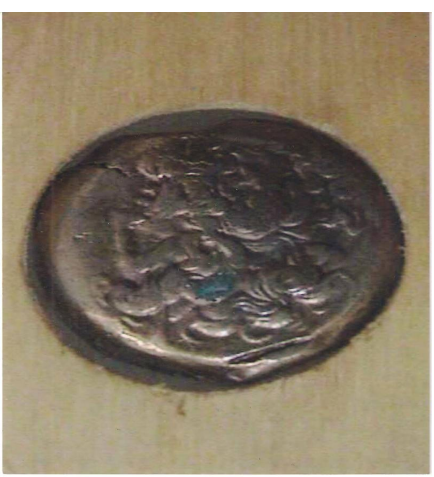

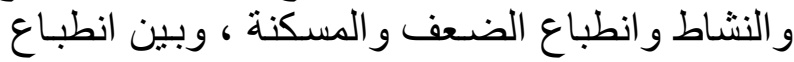

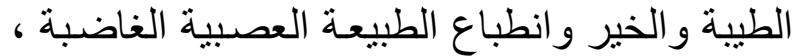

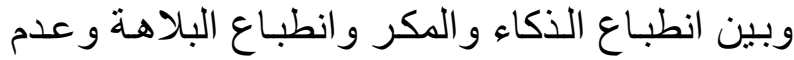

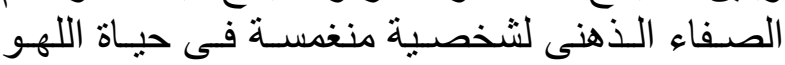
و المجون . - عملة من النحاس فئة الاوكاتادر اخمة سُكت على احتى

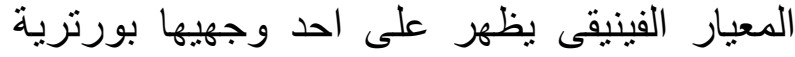

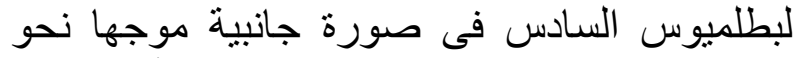

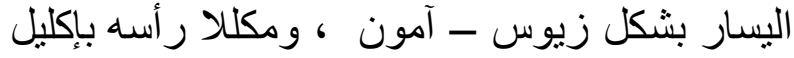
الغار و الإكليل مزين من الأمام بعنقود عنب ومن ونرتفع

21 - Smith R.R.R: Hellenistic Sculpture, 1991. 
دراسات في آثار الوطن العربيَ 1 أو

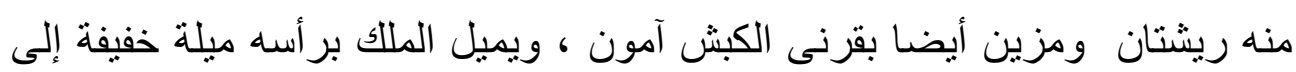
الأمام . مأه

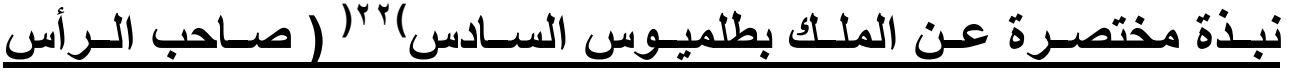

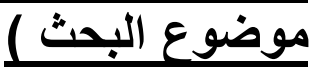

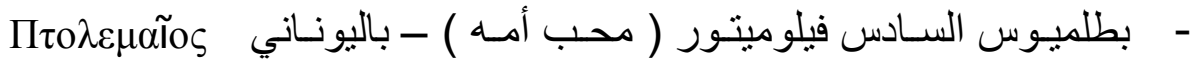
نو -

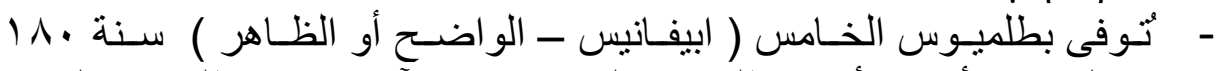

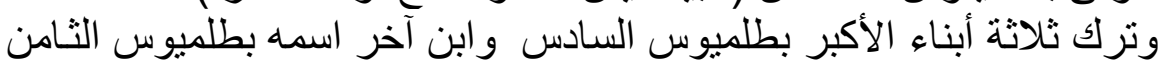

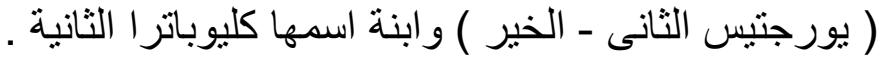

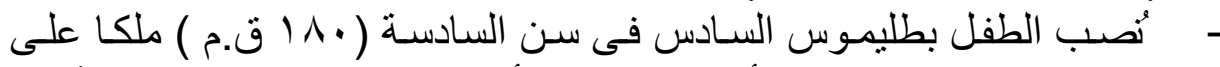

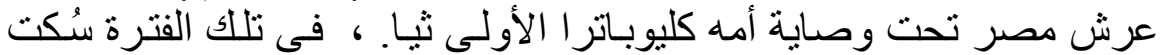

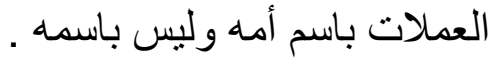

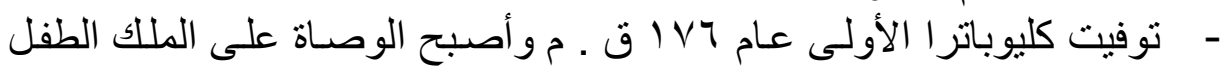

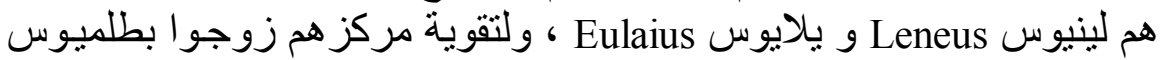

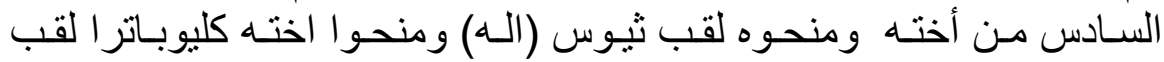

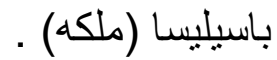

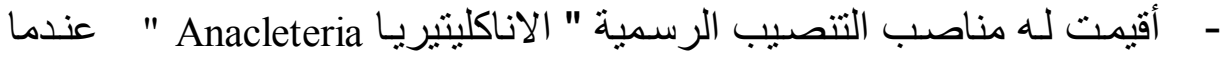

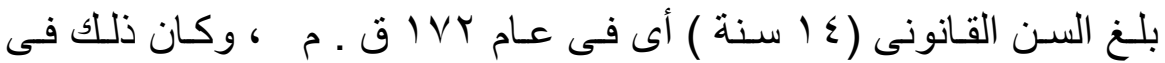

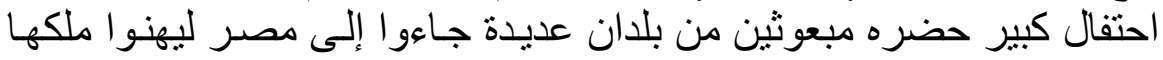

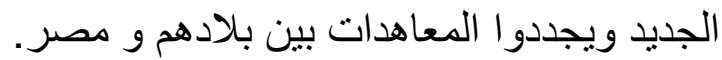

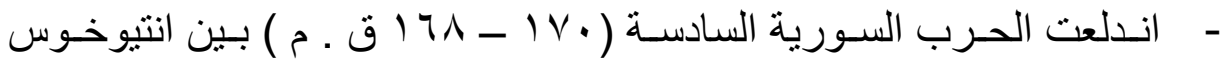

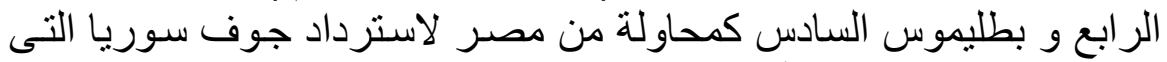

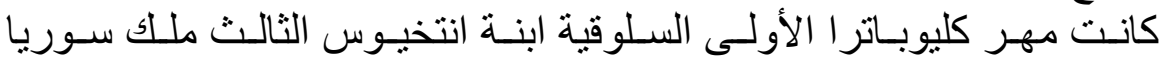

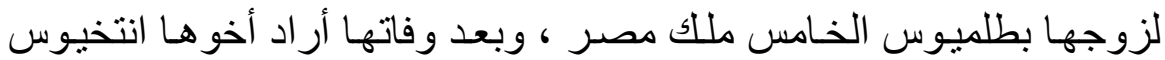

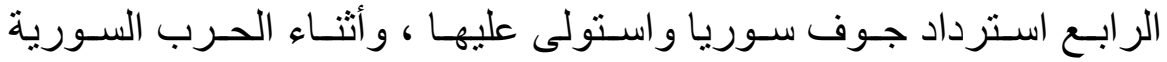

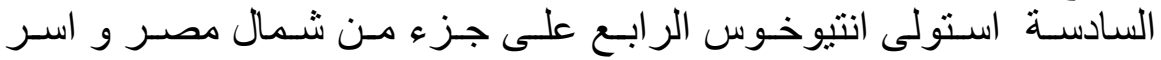

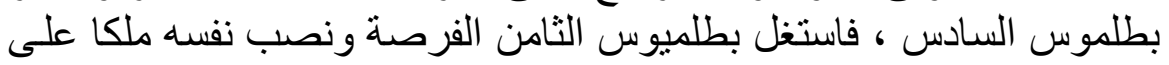

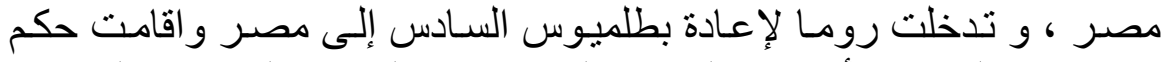

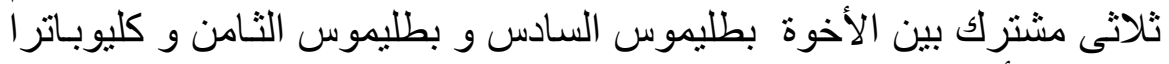

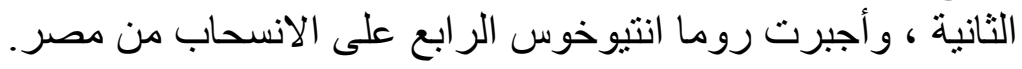


دراسات في آثار الوطن العربيَ 1

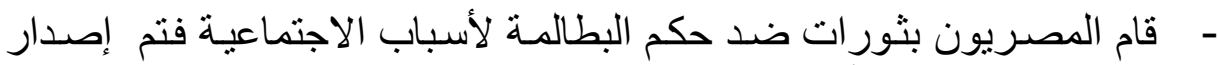

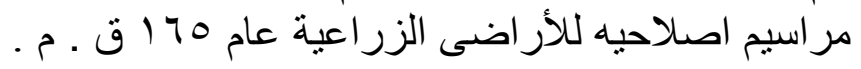

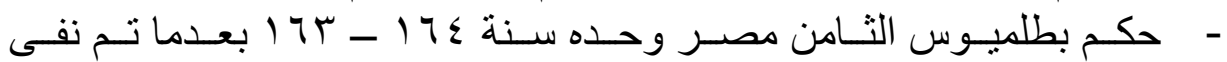

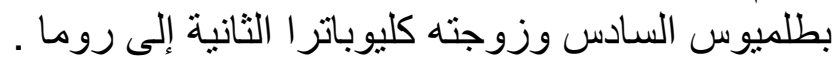

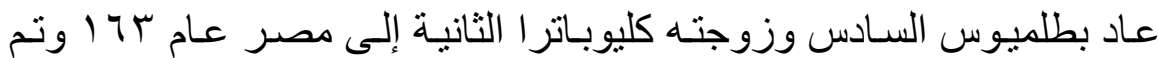

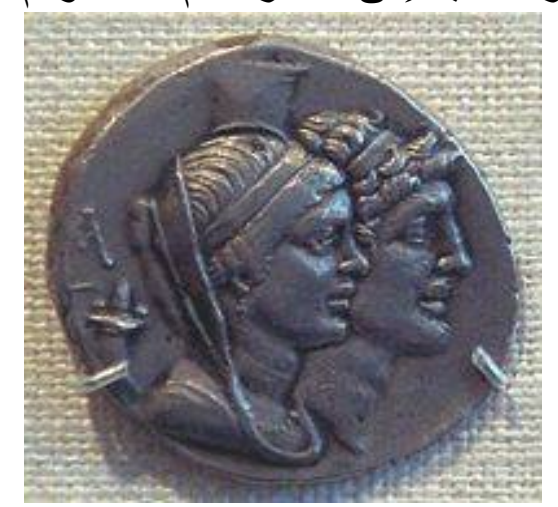

عملة لالكساندر بالاس وكليوباتر ا ابنة بطلميوس السادس محفوظة في لالنئ متحف الميتروبوليتان للفن

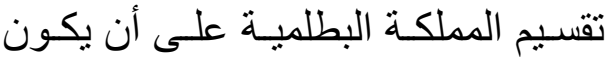

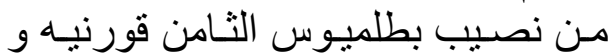

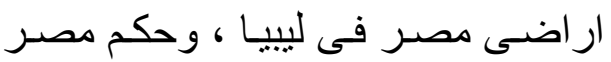

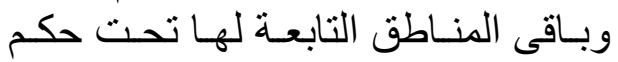
بطلميـوس السـادس وزوجتــه كليوبـاتر التون الثانية

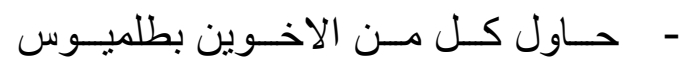
السادس و الثامن استمالة مجلس الثيون

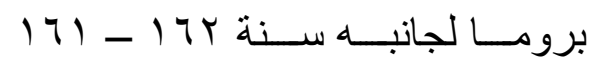

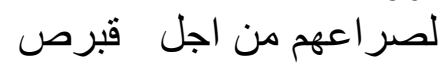

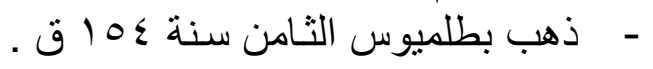

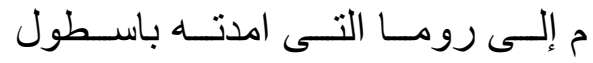

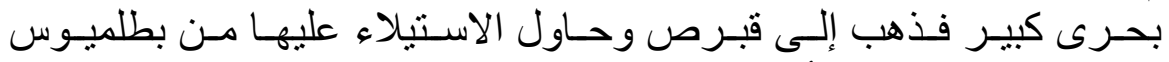

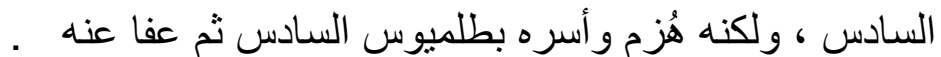

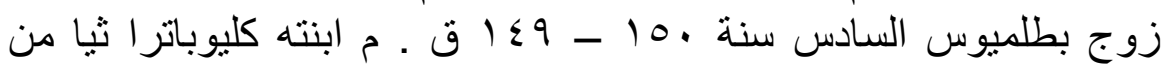

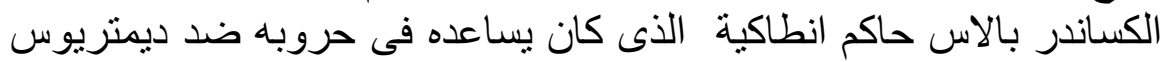

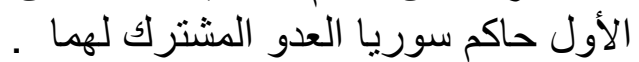

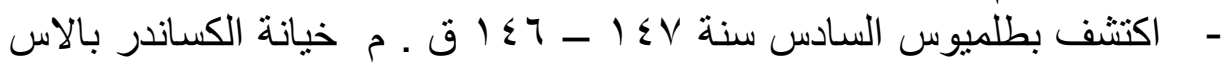

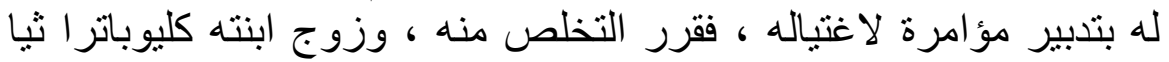

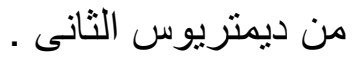

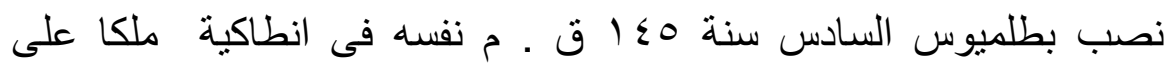

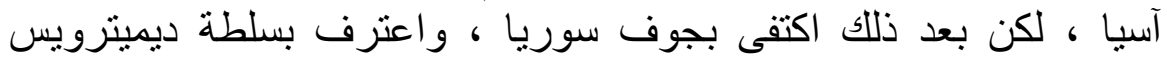
التانى على آسيا.

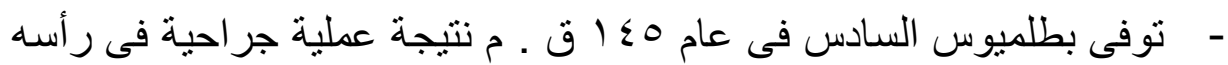

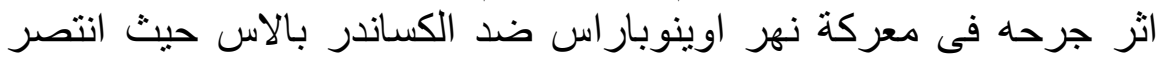
بطلميوس السادس . 


\section{الخاتمة}

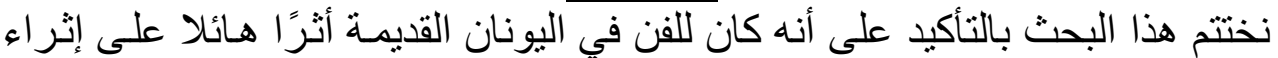

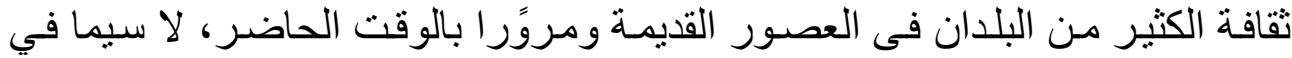

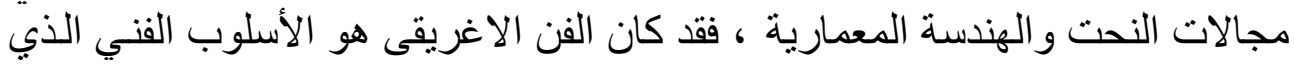

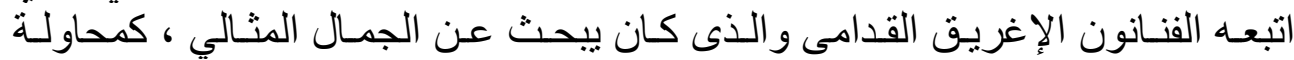

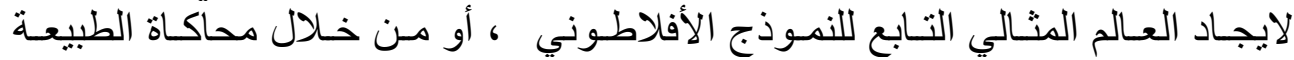

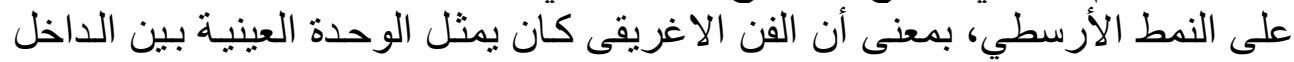

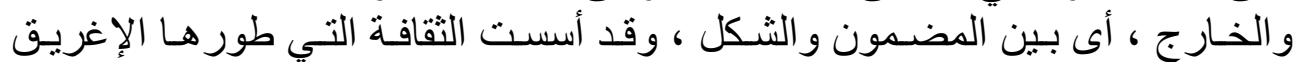

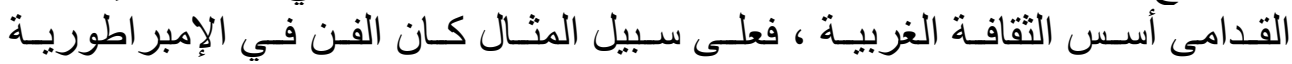

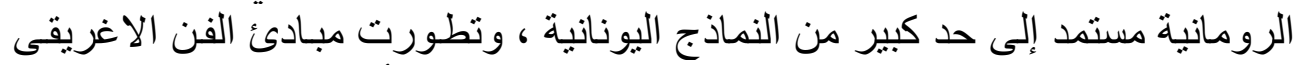

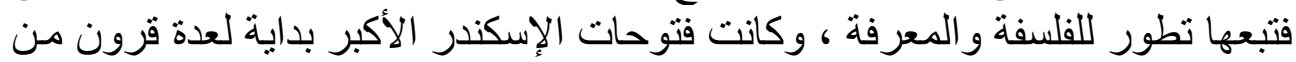

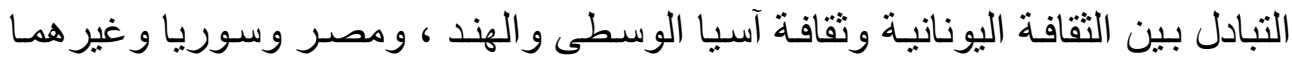

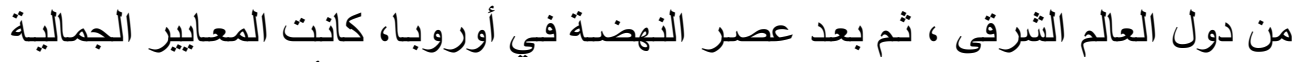

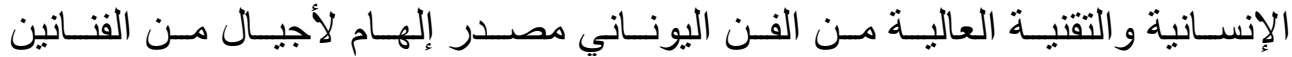

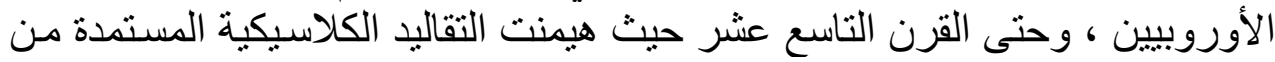

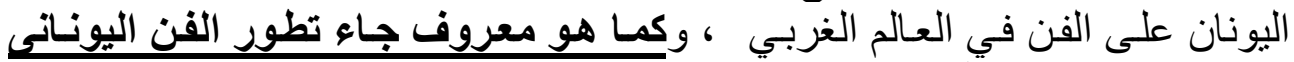

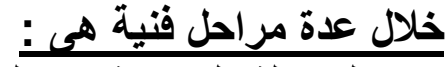
• المرحلة الهندسية في القرنية هين التاسع والثامن قبل الميلاد، هنالك معلومات قليلة

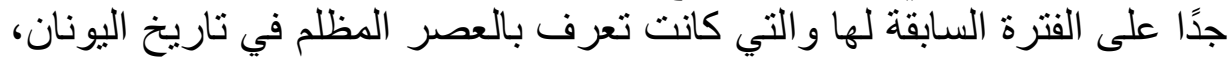

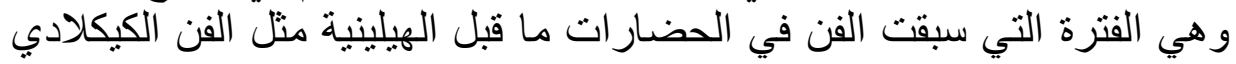

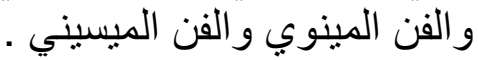
المرحلة المتقلّة بالفينيقيين وآثنور، من نهاية القرن الثامن وبدايات القرن السابع

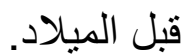
المرحلة القديمة ، في القرنين السابع و السادس، وظهرت في الزئ في الزخرفة التصويرية

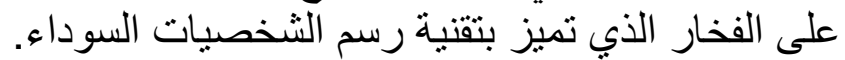

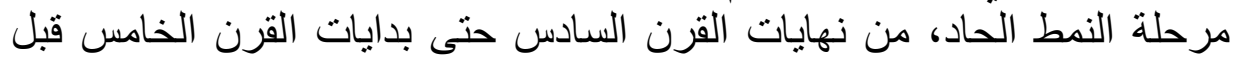

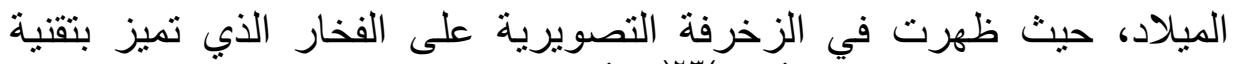

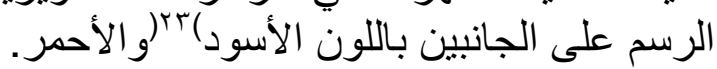

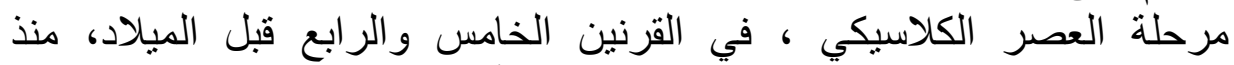

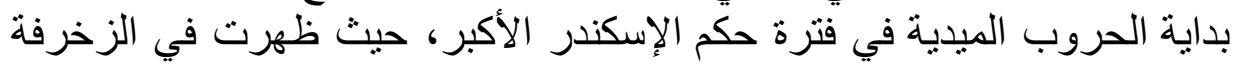

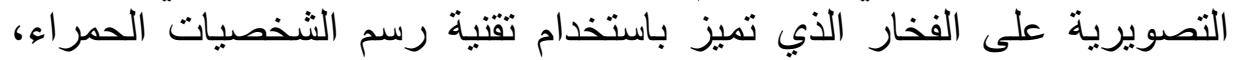
و الذي امتد حتى الحقبة اللاحقة له له لهيز 


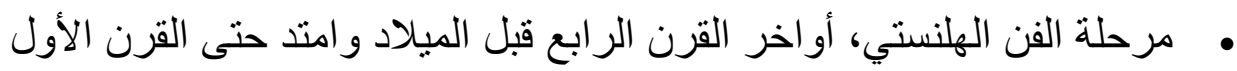

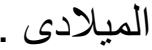

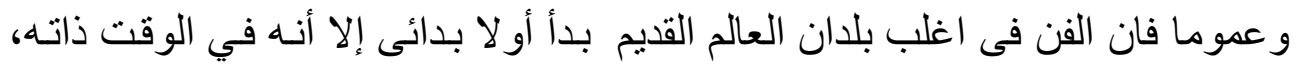

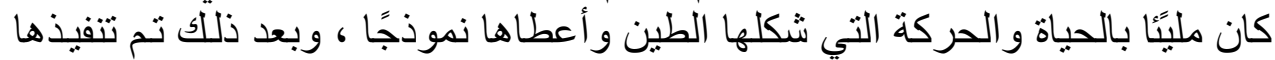

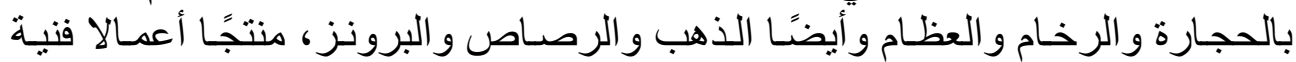

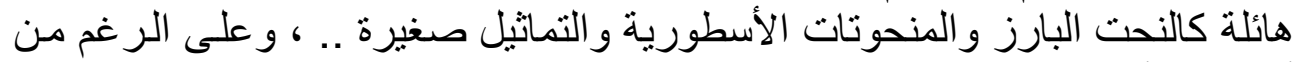

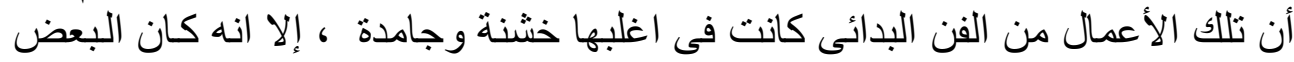

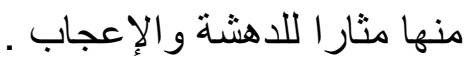

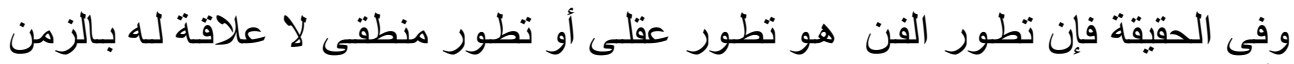

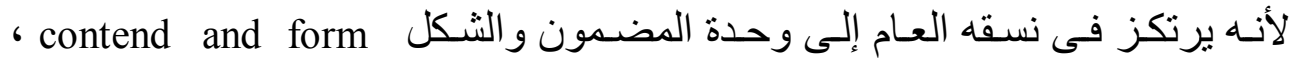

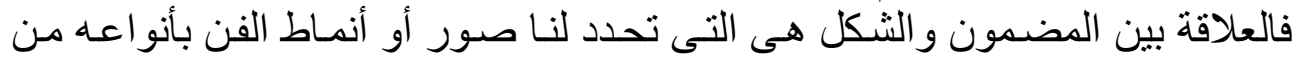

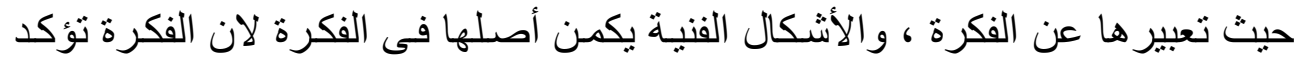

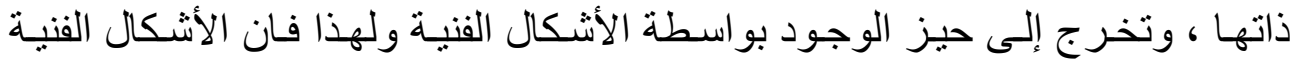

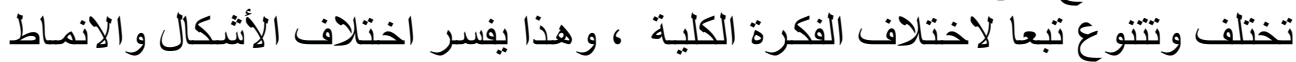

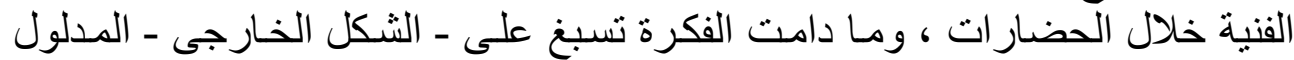

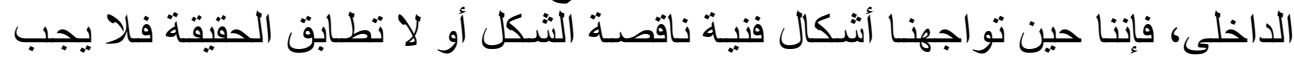

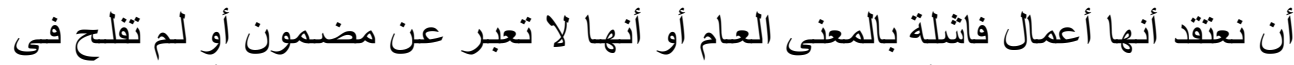

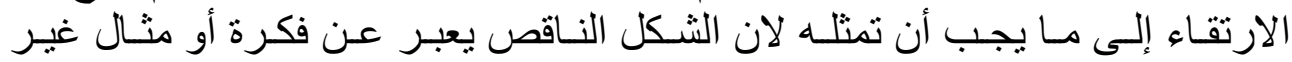

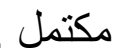
ومما هو جدير بالذكر فانها بالر غم من أن الإغريق مدينون إلى أسلافهم الثـرقيين

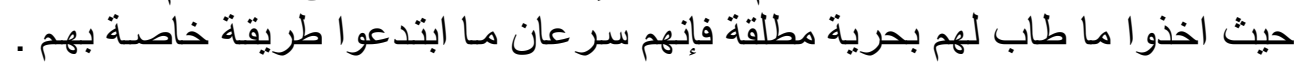

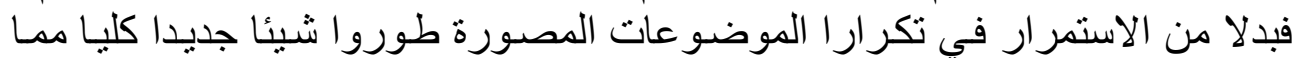

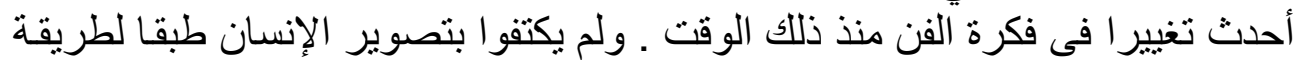

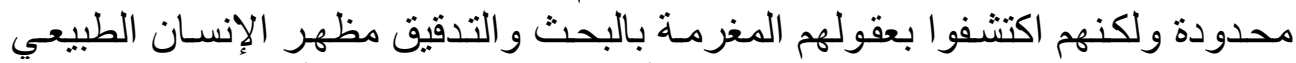

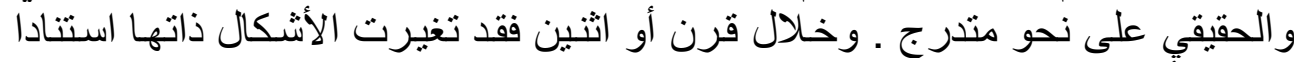

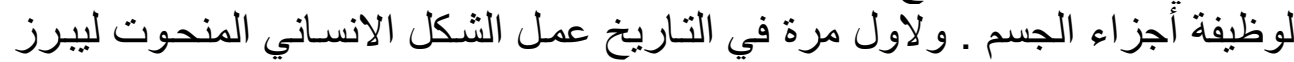

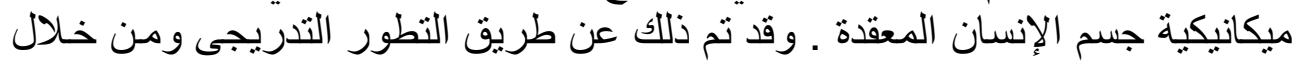

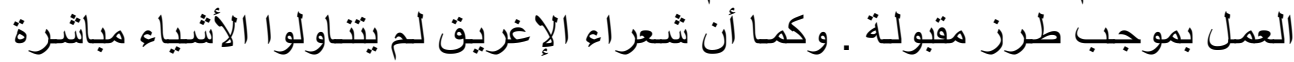

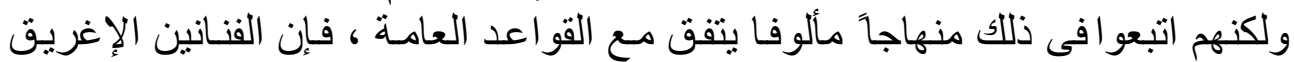

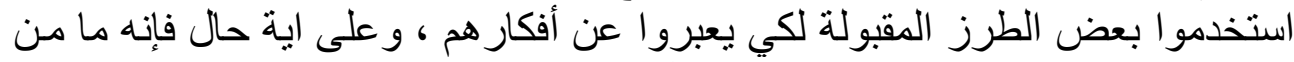

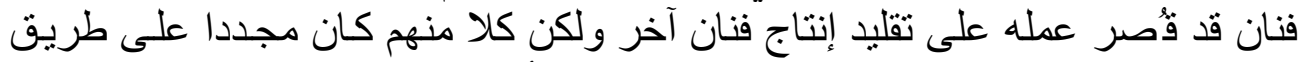

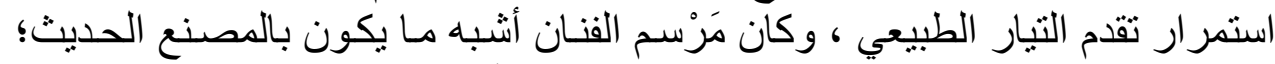

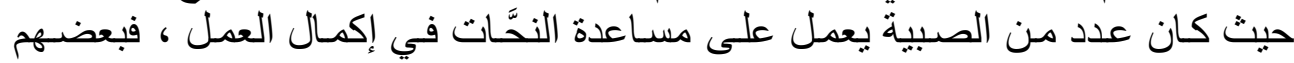


دراسات في آثار الوطن العربيه 1

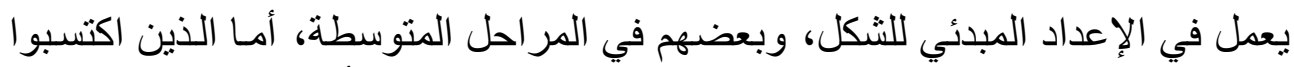
قدرًا كافيًا منهم من الإعدريب النيب و الخبرة فيساعدون في المر احل الأخيرة للعمل الفني.

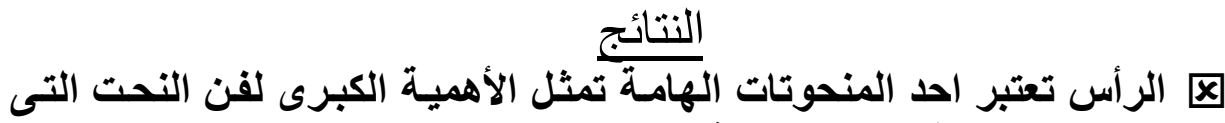

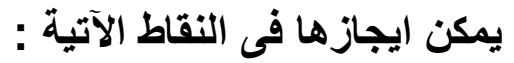
ا

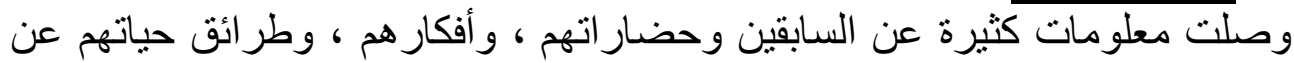

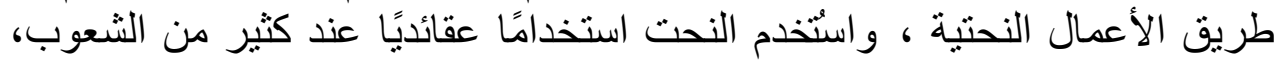

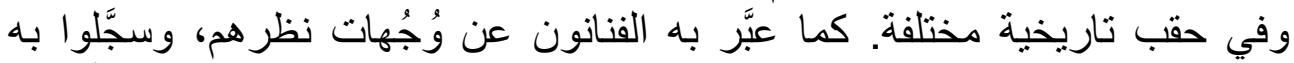

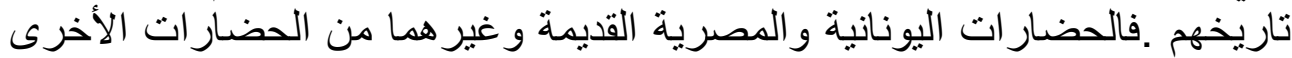

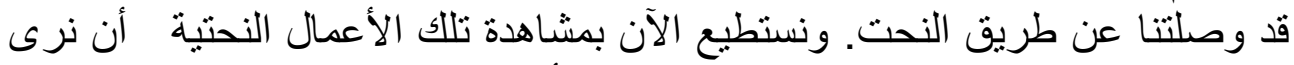

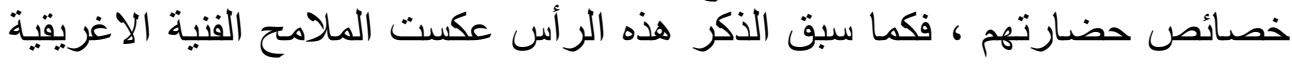

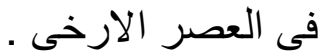

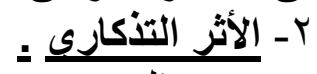

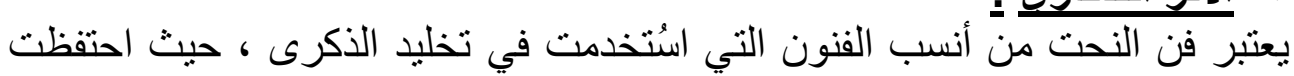

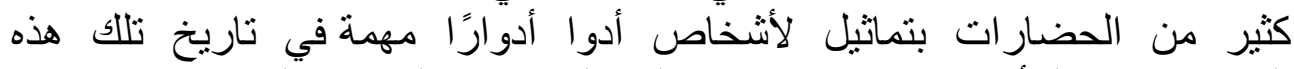

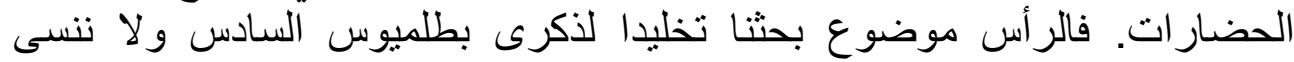

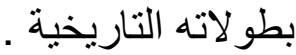
ب- ك- التعبير الفنى. يُنتج كثير من الفنانين أعمالهم من أجل إثباع حاجاتهم الابتكارية ؛ أو للاتصال

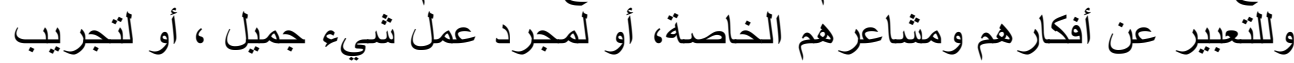

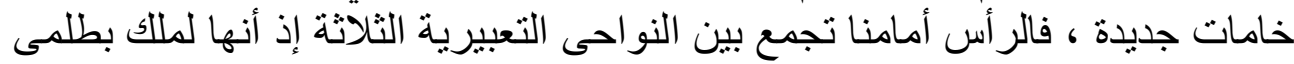

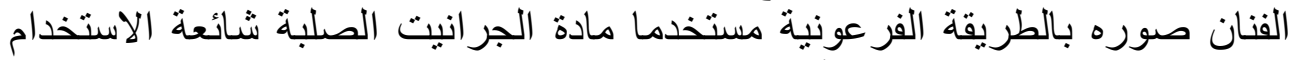

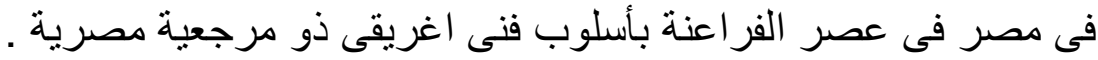
ع - جزء من من العمارة.

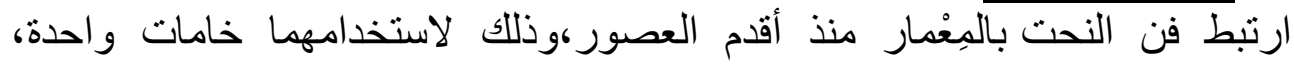

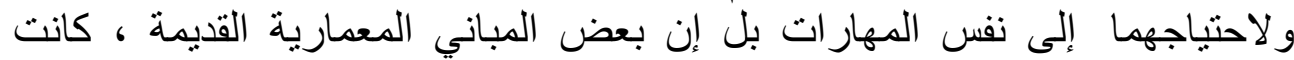

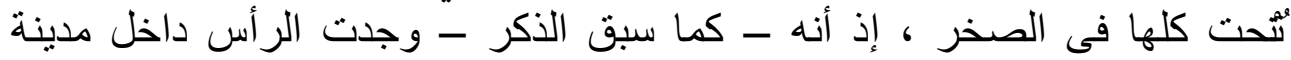

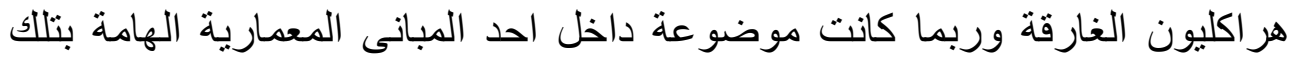

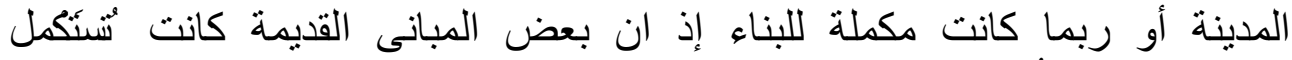

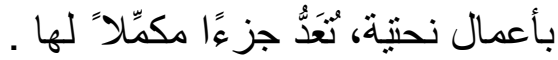

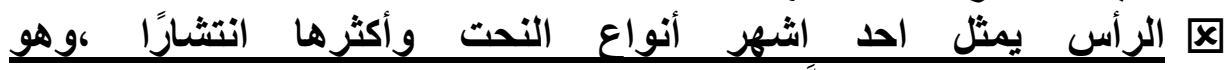

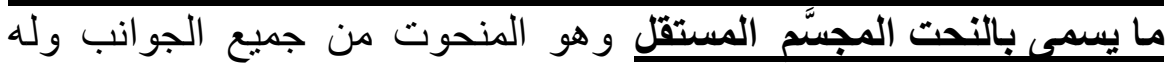


دراسات في آثار الوطن العربيه 1

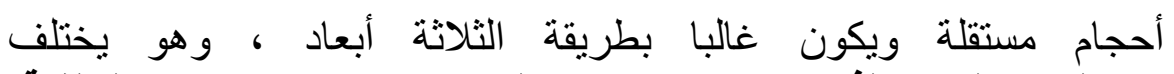

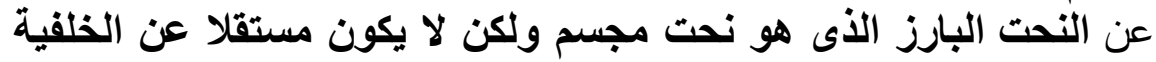

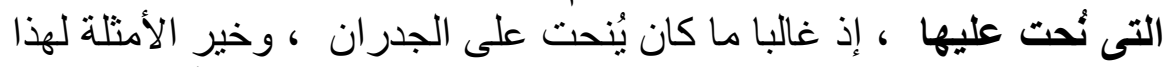

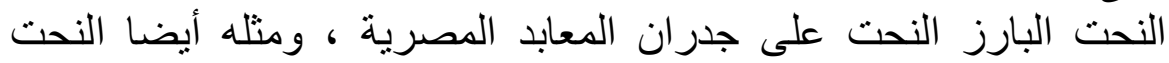

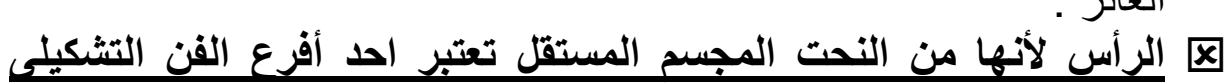

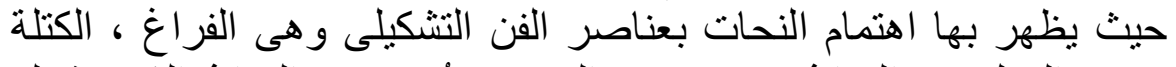

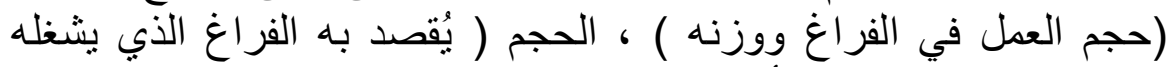

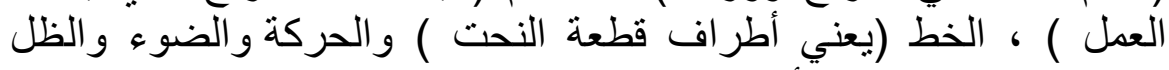

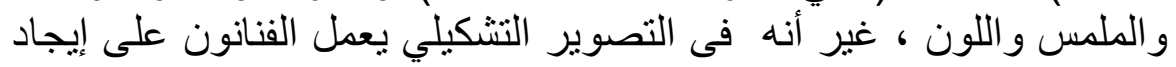

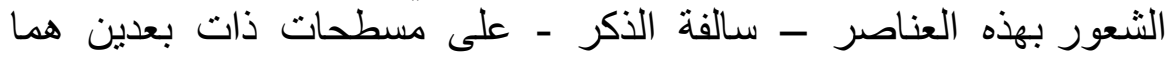

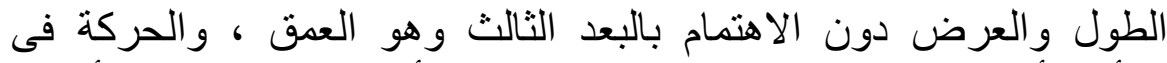

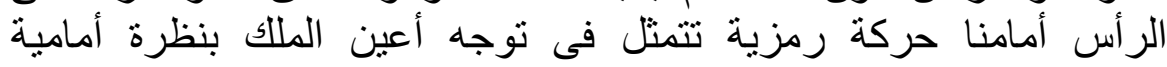

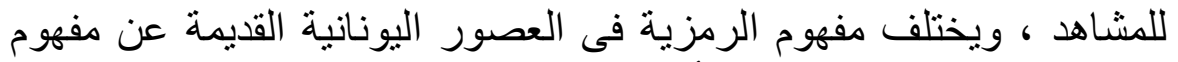

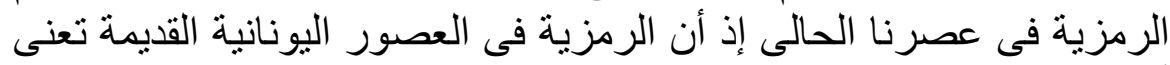

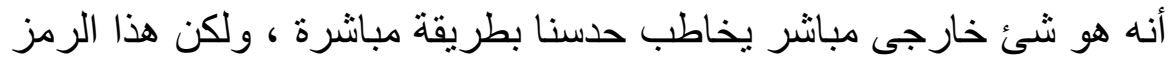

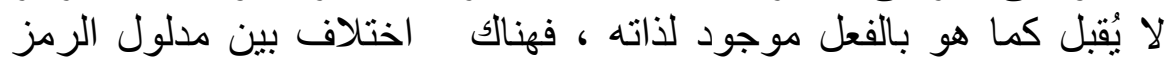

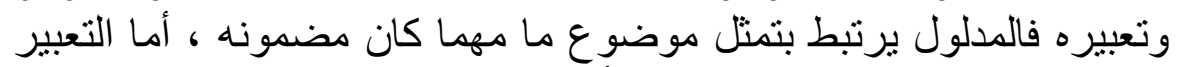

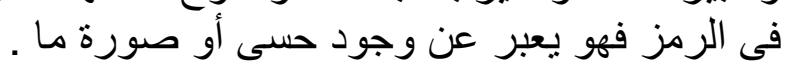

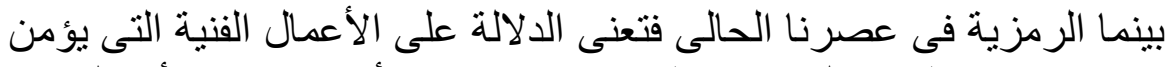

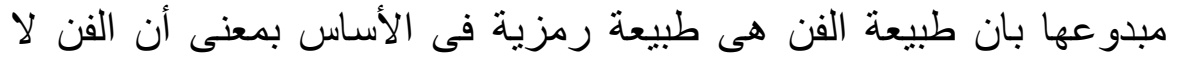

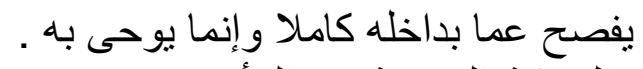

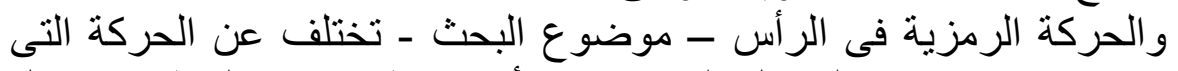

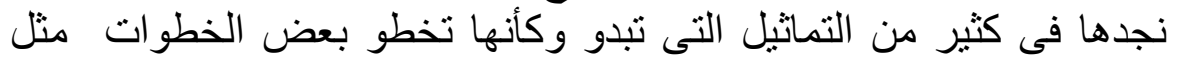
تماثيل الكوروس ، هذير هذا بخلاف التماثيل ذاتية الحركة التى كانيل كانت تتحرك

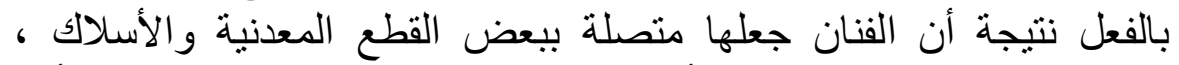

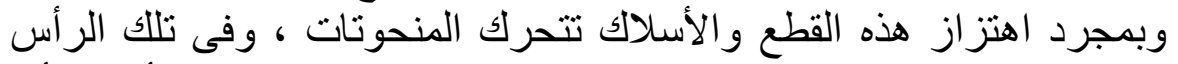

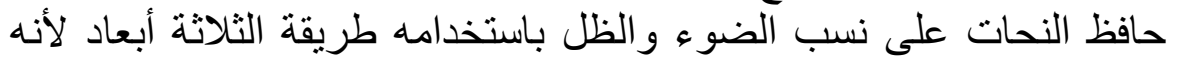

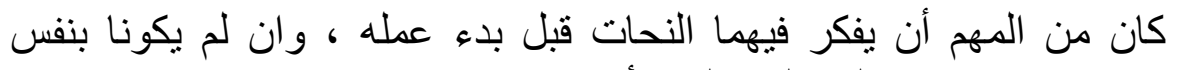

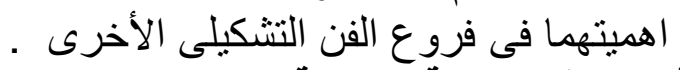

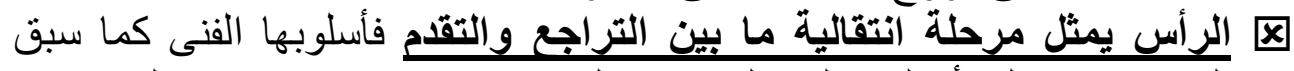

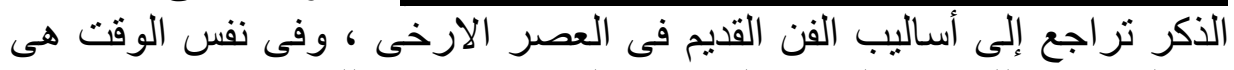

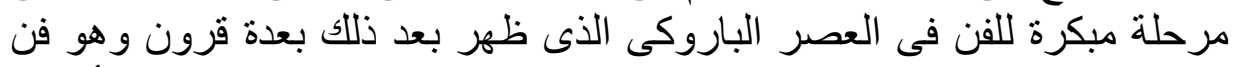
على صلة وثيقة ونشيطة مع ما هو موجود في الحئي ظهياة بهدف تحويلها إلى أعمال 
دراسات في آثار الوطن العربي، 1

خالدة ، و هو طر از معقد يستمد خصوبته من عمق الو اقع فهو فن اللحظة الآنية

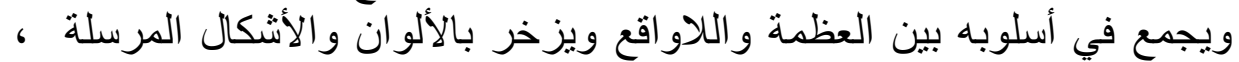

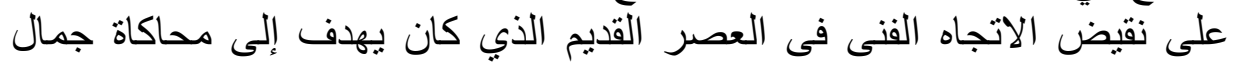

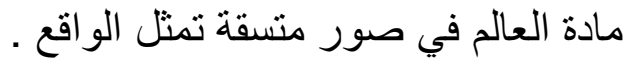

